\title{
THE CONSTITUTIONAL STATUS OF THE LAWFULLY ADMITTED PERMANENT RESIDENT ALIEN: THE INHERENT LIMITS OF THE POWER TO EXPEL*
}

\author{
SIEGFRIED HESSE $\dagger$ \\ [O]nce you start a mistake, the trouble is done \\ and you never know what is going to come of it. \\ Mark Twain ${ }^{1}$
}

As has been demonstrated, prior to 1917 no statute authorized the expulsion, for postentry conduct, of aliens not considered initially excludable. ${ }^{2}$ Consequently, none of the pre-1917 cases had actually considered the constitutional power of Congress to expel the lawfully admitted long-term resident alien, whose postentry behavior does not support a presumption of erroneous or illegal entry.

\section{The Road to Banishanent \\ Legislation-1917-1939}

With respect to ejection, ${ }^{3}$ the form of the Act of February $5,1917,{ }^{4}$ marked a new departure. Instead of providing for generally applicable limited time periods within which excludability had to be shown, as did sections 20 and 21 of the 1907 act, 5 the 1917 act specified the grounds for expulsion-and their concomitant time limits or lack thereof-separately. And with the exception of provisions affecting limited classes, ${ }^{6}$ it abandoned the approach of former

\footnotetext{
*The second of two Articles by the author. The first appears in volume 68 at page 1578.

$\dagger$ Managing Legal Editor, California Continuing Education of the Bar. The vicws expressed here are those of the author, and do not necessarily represent those of either the State Bar of California or the University of California Extension, which administers the program.

1. Twain, A Connecticut Yankee in King Arthur's Court 124 (Modern Library ed. 1917).

2. See Hesse, The Constitutional Status of the Lazefully Admilted Permancm Resident Alien: The Pre-1917 Cases, 68 YALE L.J. 1578, 1610-18 (1959) (hercinafter cited as Hesse, The Pre-1917 Cases]. The Supreme Court recognized this fact in Kessler v. Strecker, 307 U.S. 22, 31 (1939).

3. For purposes of this Article, "ejection" is "the expulsion of ... [an alien] who either entered illegally, or who, within a reasonable time after entry, committed acts justifying the conclusion that entry was erroneously allowed." "Banishment" means the expulsion of "one who committed an act which either by its nature, or by its temporal remoteness to entry, affords no basis for a presumption of initial excludability." "Expulsion" includes both ejection and banishment. Hesse, The Pre-1917 Casis 1580-81.

4. Ch. 29,39 Stat. 874 .

5. Act of Feb. 20, 1907, ch. 1134, $\S$ 20, 21, 34 Stat. 904-05.

6. E.g., alien seamen. Act of Feb. 5, 1917, ch. 29, § 34, 39 Stat. 896.
} 
section 3, which had provided that aliens committing expellable acts within the specified time period "shall be deemed to be unlawfully within the United States."7 Section 19 of the 1917 act simply set up classes of expellable aliens who were to be "taken into custody and deported."8 These textual changes obscured the fundamental distinction between provisions specifying the time within which initial excludability could be proved, and provisions defining those "expellable acts" which operated as substitutes for such proof."

Nonetheless, portions of the legislative history tend to show that the redrafting was not meant to effect any substantive change in the theory upon which postentry ejection was based. The Senate Report stated that:

[The purpose of the change] is to make perfectly clear the intent to continue the practice established when the act of 1907 was passed of expelling from the United States every alien who, after having secured admission in one way or another, was found here within the period of limitation fixed and was found to have been at the time of his entry a member of any one of the list of classes enumerated in section 2 of the said act, $\ldots . .^{10}$

The Report also noted that in many cases the Supreme Court had regarded deportation as deferred exclusion. ${ }^{11}$ Thus, it would seem that section 19 was intended to deal only with the illegally or erroneously admitted alien.

In commenting on the elimination of generally applicable time limitations, however, the Report took a broad view of congressional power. It was announced that the policies of the Act of March 26, 1910, providing for deportation of prostitutes, procurers, and the like, without regard to time of entry, were being extended to cover other undesirable classes, such as anarchists. ${ }^{12}$ The Report asserted that these 1910 provisions had been "emphatically and distinctly upheld" by the Supreme Court, ${ }^{13}$ and implied that extension of this policy to other classes was equally proper. In effect, this amounted to a claim that whenever Congress found the conduct of certain classes of aliens undesirable, it could equate undesirability with proof of initial excludability and therefore apply expulsion provisions unlimited in time. Disre-

7. Act of Feb. 20, 1907, ch. 1134, § 3, 34 Stat. 900.

8. Ch. $29, \S 19,39$ Stat. $889-90$.

9. Some grounds for expulsion were related to initial excludability in express terms. E.g., the public charge provision: "any alien who within five years after entry" becomes a public charge from causes not affirmatively shown to have arisen subsequent to landing." Ch. $29, \S 19,39$ Stat. 889. But in defining other expellable classes, such as prostitutes, no reference to initial excludability was made.

10. S. REP. No. 352, 64th Cong., 1st Sess. 14 (1916). Compare Congress' 1950 view oi the 1917 act: "[It] made radical changes in requiring the deportation after entry in an extensive class of cases and in permitting deportation without time limitation in certain cases." S. REp. No. 1515, 81st Cong., 2d Sess. 5455 (1950).

11. S. REP. No. 352, 64th Cong., 1st Sess. 16 (1916).

12. Id. at 15 .

13. Ibid. The case cited in support of this statement, Lapina v. Willinms, 232 U.S. 78 (1914), did not involve the 1910 provisions. 
garded in this assertion of power were the facts that the 1910 legislation had been based in part on a finding that illegally or erroneously admitted prostitutes avoided expulsion by lying about time of entry, thus making it necessary to remove the time limitations in order to expel all those initially excludable, ${ }^{14}$ and that the cases upholding this legislation ${ }^{15}$ did not involve aliens who were able to prove that they were not initially excludable. ${ }^{10}$

Thus, while iCongress still purported to recognize that ejection was delayed exclusion, it denied that a causal connection between preentry characteristics and postentry conduct was necessarily relevant to the exercise of the ejection power, and, accordingly, actually divorced ejection from excludability. Moreover, by eliminating old section 3's express language showing the presumption of initial excludability upon which postentry expulsion was originally based, Congress gave section 19 the appearance of a number of special statutes of limitation. As a consequence, time limitation periods readily became accepted as the boundaries of the Government's grace rather than of the extent of its power.

The Act of October 16, 1918, ${ }^{17}$ in effect an amendment of the 1917 act, ${ }^{10}$ eliminated the five-year limitation period for aliens who were anarchists at entry, expanded the excludable classes, and made membership in these classes cause for expulsion in all cases, thus extending the grounds for expulsion beyond those prescribed in the 1917 act. $^{10}$ One of the purposes of the 1918 act was to eliminate the necessity of proving that those who had been anarchists at entry, but who were not expellable because of five years' residence, had later committed an expellable act. ${ }^{20}$ But nothing in the 1918 act or its amendments ${ }^{21}$ goes beyond the congressional view, expressed in the 1917 act, of the basis and scope of legislative power. ${ }^{22}$

Up to 1920 , the grounds for exclusion had been qualitative, not quantitative. $^{23}$ In 1921, however, quota provisions were enacted as an emergency measure, ${ }^{24}$ and in 1924 became a permanent part of United States immigra-

14. See Hesse, The Pre-1917 Cases 1617 nn.248-49.

15. E.g., Bugajewitz v. Adams, 228 U.S. 585 (1913).

16. See Hesse, The Pre-1917 Cases 1621-25.

17. Ch. 186, 40 Stat. 1012.

18. H.R. REP. No. 645, 65th Cong., 2d Sess. 1 (1918).

19. See Kessler v. Strecker, 307 U.S. 22, 32 (1939). The changes in the exclusion provision were purportedly only what Congress had intended by the more general language of the 1917 act. See H.R. REP. No. 645, 65th Cong., 2d Sess. 1-2 (1918).

20. Id. at 2-3.

21. Act of June 5, 1920, ch. 251, 41 Stat. 1008. The 1920 act was enacted for the purpose of circumventing the Secretary of Labor's ruling that IWW membership was not per se an expellable act. See H.R. REP. No. 504, 66th Cong., 2d Sess. 5 (1919).

22. The only other expulsion legislation of this period, the Act of May 10, 1920, ch. 174, 41 Stat. 593, authorized expulsion of those convicted of certain war crimes. For a discussion of this legisiation, see Hesse, The Pre-1917 Cases 1584-86.

23. The literacy requirement in the 1917 act, however, actually had the effect of excluding quantitatively; it was on this ground that President Wilson vetoed H.R. 6060, 63d Cong., 3d Sess. (1915). See H.R. Doc. No. 1527, 63d Cong., 3d Sess. 4 (1915).

24. Act of May 19, 1921, ch. 8, 42 Stat. 5. 
tion law. ${ }^{25}$ While quota exclusion did not replace qualitative exclusion, quota enforcement, which produced a race to the ports by both shipping companies and immigrants, ${ }^{26}$ compelled Congress to establish, in the 1924 act, a uniform system of preexamination. ${ }^{27}$ Every lawful immigrant now was required to have a visa, which for all practical purposes established both time and manner of entry. ${ }^{28}$ Accordingly, the 1924 act shifted the burden of proof of these matters in deportation proceedings to the immigrant.20 Moreover, the application for the required visa established whether a prospective entrant was coming for temporary or permanent residence. ${ }^{30}$

These changes in the regulation of entry into the United States not only simplified the process of exclusion, but they eliminated the original justification for the adoption of postentry expulsion provisions unlimited in time. ${ }^{31}$ With time, place, and manner of entry now generally determinable, the extent of congressional power to eliminate time limitations on the raising of presumptions of excludability from postentry conduct ceases to be a question of the practical difficulty of proof of time of entry, but becomes solely one of how far back in time such a presumption can rationally be extended. But, prior to Harisiades v. Shanghnessy, ${ }^{32}$ the cases involving the post-1917 legislation brought forth no substantial challenge to congressional power. The textual shift made in 1917 had submerged the question, and the lack of limits soon became an accepted constitutional axiom.

\section{Judicial Erosion of the Constitutional Status of the Resident Aliens}

Ng Fung Ho: Reconsidering the Status of the Illegal Entrant

$\mathrm{Ng}$ Fung Ho v. White ${ }^{33}$ presented the question whether Chinese persons who had entered in violation of the Chinese Exclusion Acts prior to the 1917 act could be deported under the administrative procedures prescribed in the latter act. ${ }^{34}$ Prior to the 1917 act, the Supreme Court had held that judicial

25. Immigration Act of 1924, ch. 190, 43 Stat. 153 (reenacted in seattered sections of Immigration and Nationality Act of 1952, 66 Stat. 163, 8 U.S.C. $\S \S 1101-1503$ (1958)).

26. H.R. REP. No. 176, 68th Cong., 1st Sess. 5 (1924).

27. "The use of immigration certificates affords not only a ready and appropriate means of enforcing the numerical limitation, but a proper and reasonable method of examining the intending immigrant before he sets sail for the United States." Ibid.

28. Immigration Act of 1924, ch. 190, § 7, 43 Stat. 156-57.

29. Ch. 190, § 23, 43 Stat. 165-66. It has been suggested that once the alien has proved time and manner of entry, the burden of proving his expellability shifts to the Government. See Developments in the Law-Immigration and Nationtality, 66 HARv. L. Rev. 643, 693 n.380 (1953) ; cf. United States ex rel. Vajtauer v. Commissioner of Immigration, 273 U.S. 103,110 (1927).

30. Ch. 190, § 7(b), 43 Stat. 156.

31. See Hesse, The Pre-1917 Cases 1617 nn.248-49.

32. 342 U.S. 580 (1952).

33. 259 U.S. 276 (1922).

34. This clearly was the result Congress intended. See S. REp. No. 352, 64th Cong., 1st Sess. 14 (1916). 
proceedings were necessary for ejection based on violation of the Chinese Exclusion Acts. ${ }^{35} \mathrm{Mr}$. Justice Brandeis, however, apparently regarded that case as an interpretation of the Exciusion Acts and not as a determination of a possible constitutional issue.

The mere fact that at the time petitioners last entered the United States they could not have been deported except by judicial proceedings presents no constitutional obstacle to their expulsion by executive orcler now. Neither ... claims to be a citizen of the United States. Congress has power to order at any time the deportation of aliens whose presence in the country it deems hurtful; and may do so by appropriate executive proceedings. Bugajewitz v. Adams ... L Lapina v. Williams . . . Lewis v. Frick .... Our task, therefore, so far as concerns these two petitioners, is merely to ascertain the intention of Congress. ${ }^{36}$

This portion of the opinion, often relied on to support the power of Congress to expel, ${ }^{37}$ is readily seen to have considered only procedural due process, not substantive limits to the expulsion power. Indeed, since the aliens involved had been residents less than five years, ${ }^{38}$ no serious substantive question could have arisen.

More difficulty arises from Mr. Justice Brandeis' interpretation of the 1917 act as not requiring retrospective application. He reached this conclusion by arguing that unlawful entry and unlawful remaining were separate offenses. ${ }^{30}$ The cases cited in support of this position, however, all involved presumptive. ly unlawful entrants under the Chinese Exclusion Acts, which prescribed the means of proof of lawful entry. 40 In Brandeis' opinion, the failure to prove lawful entry became an unlawful remaining. Such a formulation can be ap. proved only so long as it is recognized that the unlawful remaining relates to the initial right to enter, a connection not made by Brandeis.41 The attempt to draw a distinction between unlawful entry and unlawful remaining tended to obscure the basis upon which the power to expel rests. Although $\mathrm{Ng}$ Fung

35. United States v. Woo Jan, 245 U.S. 552 (1918).

36. 259 U.S. at 280.

37. See, e.g., Galvan v. Press, 347 U.S. 522,532 (1954) ; Carlson v. Landon, 342 U.S. 524, 534 n.18 (1952).

38. 259 U.S. at 278 .

39. 259 U.S. at $280-81$.

40. The cases in the order cited were Fong Yue Ting v. United States, 149 U.S. 698 (1893) ; Li Sing v. United States, 180 U.S. 486 (1901); Ah How v. United States, 193 U.S. 65 (1904). For a discussion of the view of the Chinese Exclusion Acts taken here, see Hesse, The Pre-1917 Cases 1591-97, 1612-13.

41. Since Ng Fung Ho himself was admittedly an illegal entrant, see Ng Fung Ho v. White, 266 Fed. 765,768 (9th Cir. 1920), no constitutional problem could have arisen with respect to him even if the act had been said to apply retrospectively. Cf. Johannessen v. United States, 225 U.S. 227 (1912) (one who obtained citizenship by fraud cannot object on grounds of retroactivity to legislation which deprives him of it). $\mathrm{Ng} F u n g \mathrm{Ho}$, in the Supreme Court, also dealt with two Chinese who claimed to be citizens. Brandeis held that they were entitled to a judicial hearing since they were within the United States, and not attempting to enter. 259 U.S. at 282. 
Ho actually dealt with illegal entrants and concerned a procedural issue, it eroded the constitutional status of the long-term lawful resident through broad language and strained, unrealistic, and unnecessary conceptual analysis.

\section{The Anarchist Cases}

$\mathrm{Ng}$ Fung $\mathrm{Ho}$ was followed by a series of cases involving anarchists."2 Although two involved aliens who had been residents for nine and ten years when arrested, ${ }^{43}$ in none was the power of Congress to expel questioned. Relying instead on alleged violations of procedural due process, the aliens were uniformly unsuccessful in avoiding expulsion.

\section{Mahler v. Eby: Retroactive Conditions in Wartime}

Mahler v. Eby, ${ }^{44}$ discussed elsewhere in relation to the war power, ${ }^{45}$ is significant as a part of the process of growing acceptance of unlimited congressional power. Although immediate expulsion was avoided on a technicality, the Court in effect upheld for the first time the retroactive imposition of new grounds for expulsion, unrelated to preentry characteristics-the portions of the 1920 act involved ${ }^{46}$ prescribed deportation for aliens convicted of certain war crimes and for internees. The basis of this act, however, was quite reasonable, since it merely imposed on the resident alien the condition that he refrain from detrimental wartime criminal activity, a condition probably implied at the time of entry. ${ }^{47}$

\section{The Reentry Cases}

A final class of cases which arose during this same period invoked the reentry doctrine-the theory that each time an alien returns to the United States after an absence abroad, his most recent entry is considered controlling for exclusion and expulsion purposes. ${ }^{18}$ Given this starting point, the cases are not inconsistent with the theory that expulsion for postentry acts depends on the reasonableness of basing a presumption of excludability at time of entry

42. United States ex rel. Vajtauer v. Commissioner of Immigration, 273 U.S. 103 (1927) ; United States ex rel. Mensevich v. Tod, 264 U.S. 134 (1924); United States ex. rel. Tisi v. Tod, 264 U.S. 131 (1924); United States $c x$ rel. Bilokumsky v. Tod, 263 U.S. 149 (1923).

43. United States ex rel. Mensevich v. Tod, supra note 42 (ten years); United States ex rel. Bilokumsky v. Tod, supra note 42 (nine years).

44. 264 U.S. 32 (1924).

45. Hesse, The Pre-1917 Cases 1584-85.

46. Act of May 10, 1920, ch. 174, $\$ 1,41$ Stat. 593-94.

47. Compare Case of Fries, 9 Fed. Cas. 826, 834-35 (No. 5126) (C.C.D. Pa. 1799) (Alien Act of 1798).

48. The theory was developed in the cases of Lewis v. Frick, 233 U.S. 291 (1914); Lapina v. Williams, 232 U.S. 78 (1914). It originated in Chae Chan Ping v. Unitcd States (The Chinese Exclusion Case), 130 U.S. 581 (1889). See Hesse, The Pre-1917 Cases 1589 n.86. 
on these acts. ${ }^{49}$ But when the alien's previous residence has been lengthy, the reentry doctrine simply serves to blur the constitutional issues which might be raised. For example, in United States ex rel. Volpe v. Smith, ${ }^{50}$ the alien had entered in 1906 at the age of sixteen. In 1925, he had been convicted of counterfeiting and had served his sentence. Not only was he immune from expulsion under the then existing statute, ${ }^{\text {n1 }}$ but no reasonable presumption of initial excludability seems inferrable from this particular postentry conduct. When Volpe made a short trip to Cuba in 1928, he was readmitted, but in 1930 the Immigration Service instituted deportation proceedings against him, on the grounds that at the time of his second entry he had been excludable as one who had committed a crime involving moral turpitude prior to entry. These proceedings were upheld, the Supreme Court viewing the case as easily settled by the application of the reentry doctrine. ${ }^{52}$ Thus, no significant challenge to congressional expulsion power was made in the reentry cases, and, although the opinions indicated a growing acceptance of congressional omnipotence, $^{53}$ the issue of power to banish remained unconsidered and therefore should have been regarded as unsettled.

\section{An Uncontested Banishment}

The first case involving facts which would have clearly presented the issue of the substantive limits of congressional power under the conditional-entry theory was Costanzo v. Tillinghast, decided in 1932..$^{4}$ Costanzo had entered as an infant in 1905 and was arrested for deportation as the manager of a house of prostitution in 1926. Thus, as applied to him, the 1917 act involved both retrospective application and an unreasonable presumption of initial excludability. But, during the fifteen years between the passage of the 1917 act and the arrival before the Court of a genuine banishment case, the concept of unlimited congressional power had become an accepted premise.

Counsel for Costanzo contended before the court of appeals that the proposed banishment constituted a cruel and inhuman punishment, since the alien

49. See, e.g., United States $e x$ rel. Claussen v. Day, 279 U.S. 398 (1929) (manslaughter committed within three years of last entry deportable act).

50. 289 U.S. 422 (1933).

51. The Act of Feb. 5, 1917, ch. 29, § 19, 39 Stat. 889, provided for expulsion if the alien was convicted of a crime involving moral turpitude within five years after entry.

52. 289 U.S. at $425-26$.

53. See, e.g., id. at 425 .

54. 287 U.S. 341 (1932). The facts in Costanzo are set forth in the court of appeals' opinion. Costanzo v. Tillinghast, 56 F.2d 566 (1st Cir. 1932).

Admittedly there had been a residence of nine years in United States ext rcl. Bilokumsky v. Tod, 263 U.S. 149 (1923), and one of ten years in United States ex rcl. Mensevich v. Tod, 264 U.S. 134 (1924), but the ground for expulsion in those cases was political activity, which is a matter of adult thought. The age at time of entry was not indicated in either case. If at time of entry the petitioners had been adults, their subsequent conduct might reasonably be related to their preentry beliefs. If they had entered as infants or children, however, their expulsions were banishments. 
had resided here continuously since entry and was the father of native-born citizens. $^{55}$ The court of appeals upheld the expulsion with a reluctant concurrence by one judge who felt that the preferable construction of the statute was to hold the five-year statute of limitations applicable to all deportable acts except when specifically eliminated by the phrase "at any time after entry." A deportation statute without limitation, he said, gave rise to "possibilities of shocking cruelty."

Although the concurring judge's interpretation was a permissible reading of the 1917 act's rather careless draftsmanship, it ran contrary to congressional intent. ${ }^{57}$ Yet statutory interpretation was the only issue relied on before the Supreme Court, where the constitutional issue was abandoned."s The Court, employing an involved and largely erroneous process of statutory construction, ${ }^{59}$ correctly held that Congress intended to provide for the expulsion of aliens found owning or managing a house of prostitution at any time after entry. ${ }^{60}$ Thus, banishment was approved virtually by default.

\section{Summarary}

The difficulty, if not impossibility, of proving time of entry during the first decade of this century led Congress to eliminate the time limitations within which a conclusive presumption of erroneous admittance could be raised with respect to practicing prostitutes and procurers. ${ }^{01}$ This was done despite the fact that Mr. Justice Holmes' dissent in Keller $v$. United States ${ }^{\circ 2}$ had indicated that the entire Court felt that the power to regulate immigration did not subsume unlimited power to regulate postentry conduct of resident aliens. ${ }^{63}$ While the cases which first arose under this legislation did not present factual situations which tested the extent of congressional power, ${ }^{\text {of }}$ they could be interpreted as upholding unlimited power over resident aliens. Misled by this interpretation, Congress, in the 1917 act, undertook what amounted to regulation of postentry conduct unrelated to its power to exclude, although it still paid lip service to the theoretical necessity of a causal relationship between postentry conduct and preentry characteristics or conditions. When the Court was finally presented with a case whose facts could legitimately have tested the inherent limits of the power to expel, congressional omnipotence was generally conceded, although the Court had never considered the prob-

55. Costanzo v. Tillinghast, supra note 54 , at 567.

56. 56 F.2d at 568 (concurring opinion).

57. See S. REP. No. 352, 64th Cong., 1st Sess. 14 (1916) (limitation period indicated if provided).

58. 287 U.S. at 342.

59. 287 U.S. at 344-45. Compare this interpretation of the third proviso of $\S 19$ of the 1917 act with $\mathrm{Ng}$ Fung Ho v. White, 266 Fed. 765, 767 (9th Cir. 1920).

60. 287 U.S. at 345.

61. See Hesse, The Pre-1917 Cases 1617 nn.248-49.

62. 213 U.S. 138, 149-51 (1909) (dissenting opinion).

63. See Hesse, The Pre-1917 Cases 1605-09.

64. See notes 15,16 supra and accompanying text. 
lem of banishment on its merits. And with its power to expel well accepted, Congress' next step was to legislate with the specific object of banishment. This was begun in 1940 .

\section{Banishment of the Resident Alien}

There is nothing new in this notion of the subordination of legal concepts to expediency and justice, though as zeith many an old truth there is need to restate it now and again .... .

$$
\text { Mr. Justice Cardozo or }
$$

\section{Legislative E.tercise of Power}

In 1939, after Kessler $v$. Strecker ${ }^{66}$ had held that past membership in the Communist Party was not a valid ground for expulsion, those who sought the deportation of Mr. Harry Bridges ${ }^{67}$ promptly introduced a bill in the House which provided that "notwithstanding any other provision of law" Bridges, "whose presence in this country the Congress deems hurtful," be expelled. ${ }^{68}$ A Senate Committee, however, determined that the bill presented serious constitutional problems as a bill of attainder. ${ }^{60}$ As a substitute, ${ }^{70}$ Con-

65. Cardozo, Paradoxes of Legal Sctence 64 (1928), in Selected Writings 289 (Hall ed. 1947).

66. 307 U.S. 22 (1939).

67. Some congressmen were so irate at the frustration of Bridges' expulsion that there was an attempt to impeach the Secretary of Labor and several subordinate officials for granting a stay of his expulsion proceeding pending the Court's decision in Kessler. Sec H.R. REP. No. 311, 76th Cong., 1st Sess. (1939). Deportation had been ordered for past membership in the Communist Party in United States ex rel. Yokinen v. Commissioner of Immigration, 57 F.2d 707 (2d Cir. 1932).

68. H.R. 9766, 76th Cong., 3d Sess. (1940). This probably marks the highwater mark of the misconception of Mr. Justice Holmes' opinion in Bugajewitz v. Adams, 228 U.S. 585 (1913). The Senate minority report concerning this bill demonstrates the extent to which the view of congressional omnipotence had expanded: ". . Congress, in permitting immigration, merely accords aliens the privilege or license of residing in this country; and regardless of the length of time of such residence, the privilege never ripens into a vested right to remain." S. REP. No. 2031, 76th Cong., 3d Sess., pt. 2, at 5 (1940). (Emphasis added.) The power was claimed to be "inherent in sovereignty," and several cases were quoted totally out of legislative and historical context. Id. at 5-9.

69. Id., pt. 1, at 6-8. The Committee relied heavily on a communication from the then Attorney General Robert H. Jackson which stated in part:

One of our great tasks is to assimilate them [resident aliens] into our native culture; this can only be done by a deep respect for our processes and traditions. How shall we teach this respect if the Government itself will not abide by a decision in an individual case, and makes acts whose nature is not specified, and which must have been lawful when done, the basis of deportation without hearing? ... The interests of this service can be best protected by enactment of clear and fair rules of conduct that aliens may know, so that those who obey may be unmolested and those who disobey may be expelled. And let any man be heard in his own behalf before he is doomed to exile.

Id. at 9-10.

70. See Bridges v. Wixon, 326 U.S. 135, 158-59 (1945) (concurring opinion of Murphy, J.). 
gress enacted section 23 of the Alien Registration Act of $1940,{ }^{71}$ which provided in general terms that past membership in an organization advocating the overthrow of the Government by force or violence was an expellable act. While Bridges successfully eluded this congressional net, ${ }^{72}$ other long-term residents have been subsequently banished pursuant to its provisions. ${ }^{73}$

The Government still had the burden of establishing that the organization involved advocated the overthrow of the Government by force or violence. This requirement was eliminated, for the Communist Party, by the Internal Security Act of $19500^{74}$ The Immigration and Nationality Act of 1952,70 Congress' most recent expression on this subject, although it added few new grounds for expulsion, did extend the assertion of the power to banish longterm residents in certain respects. ${ }^{70}$

\section{Judicial Acceptance of Congressional Power}

In the present decade, for the first time, banishment of American residents was squarely upheld. The decisive decisions are Carlson $v$. Landon, ${ }^{77}$ Harisiades v. Shaughnessy, ${ }^{78}$ and Galvan $v$. Press, $^{73}$ all predicated on the erroneous assumption that the issue had been settled, if not by Fong Yue Ting $v$.

71. Ch. 439, 54 Stat. 670 (1940) (Title III of this act is now Immigration and Nationality Act of 1952, $\$ \$ 261-66,66$ Stat. 223-26, 8 U.S.C. $\$ \$ 1301-06$ (1958); Title II of this act is now covered by 66 Stat. 204-08, 8 U.S.C. $\S 1251$ (1958).).

72. Bridges v. Wixon, 326 U.S. 135 (1945). The Court circumvented any major constitutional questions on the basis of the insubstantiality of the evidence, and the meaning of "affiliation." Mr. Justice Murphy, however, explored the substantive due process issues involved. Id. at 157-66.

73. See, e.g., Harisiades v. Shaughnessy, 342 U.S. 580 (1952).

Section 20 of the Alien Registration Act of 1940 added to $\S 19$ of the 1917 act a subsection (b) which added five expulsion provisions, dealing with smugglers of aliens, unlawful possessors of firearms, and violators of the Registration Act. Ch. 439, 54 Stat. 671 72.

74. Ch. 1024, § 22, 64 Stat. 1006-10 (1950) (reenacted in seattered sections of Immigration and Nationality Act of 1952, 66 Stat. 163, 8 U.S.C. $\$ \S 1101-1503$ (1958)).

75. 66 Stat. 204, 8 U.S.C. $\$ 1251$ (a) (1958).

76. While the former law provided for expulsion within five years of entry for being excludable at the time of entry, there is now no time limitation. Clause 1, 66 Stat. 204, 8 U.S.C. § 1251 (a) (1) (1958). Expulsion for entry without inspection or by fraud which was formerly limited to three years of entry, may likewise now be effectuated any time after entry. Clause 2, 66 Stat. 204, 8 U.S.C. $\& 1251$ (a) (2) (1958). Aforeover, while the provisions of the 1920 act required both the commission of certain wartime offenses and a finding of undesirableness as a resident, which could not necessarily be inferred from the conviction alone, Mahler v. Eby, 264 U.S. 32 (1924), under the present provision expulsion is prescribed for those "the Attorney General finds to be an undesirable resident of the United States by reason of any of the" designated convictions, clause 17, 66 Stat. 207, 8 U.S.C. § 1251 (a) (17) (1958).

77. 342 U.S. 524 (1952).

78. 342 U.S. 580 (1952).

79. 347 U.S. 522 (1954). 
United States ${ }^{80}$ in 1893 , at least by Bugajervitz v. Adams, ${ }^{81}$ twenty years later.

The unqualified acceptance of the power to banish was foreshadowed in some of the cases preceding Harisiades. ${ }^{82}$ At the same time, there were several cases which, despite legislative disapproval of Kessler, continued to apply the strict construction rule and other devices to expulsion provisions in order to avoid unjust results. ${ }^{83}$ Of particular interest is Jordan v. DeGcorge, ${ }^{84}$ in which the Court, on its own motion, ${ }^{85}$ applied the void-for-vagueness rule to the section of the statute providing for expulsion for the commission of two crimes involving "moral turpitude" at any time after entry. ${ }^{80}$ Although this rule ordinarily applies only to criminal laws, it was here applied to the expulsion statutes in view of the "grave nature of deportation." 87

Mr. Chief Justice Vinson briefly noted the purpose of the rule, maintaining a verbal distinction between the expulsion laws and criminal statutes:

The essential purpose of the "void for vagueness" doctrine is to warn individuals of the criminal consequences of their conduct .... [But] it should be emphasized that this statute does not declare certain conduct to be criminal. Its function is to apprise aliens of the consequences which follow after conviction and sentence of the requisite two crimes.

The test is whether the language conveys sufficiently definite warning as to the proscribed conduct when measured by common understanding and practices. ${ }^{88}$

Applying this test, the majority held the moral turpitude clause valid. But there were vigorous dissenting views in an opinion by Mr. Justice Jackson, ${ }^{80}$

80. 149 U.S. 698 (1893); see Hesse, The Pre-1917 Cases 1591-97.

81. 228 U.S. 585 (1913); see Hesse, The Pre-1917 Cascs 1618-25.

82. See Johnson v. Eisentrager, 339 U.S. 763, 770-71 (1950) (reference to "probationary residence") ; United States $e x$ rel. Eichenlaub v. Shaughnessy, 338 U.S. 521,529 (1950) ("There is no question as to the power of Congress to enact a statute to deport aliens because of past misconduct." ).

83. For examples of the strict construction technique, see Fong Haw Tan v. Phelan, 333 U.S. 6 (1948); Delgadillo v. Carmichael, 332 U.S. 388 (1947).

84. 341 U.S. 223 (1951).

85. Id. at 229.

86. Act of Feb. 5, 1917, ch. $29, \S 19,39$ Stat. $889-90$ (now Immigration and Nationality Act of $1952, \S 241$ (a) (4), 66 Stat. 204, 8 U.S.C. $\$ 1251$ (a) (4) (1958)).

87. 341 U.S. at 231.

88. Id. at $230-32$.

89. Id. at 232-45. Jackson noted the Government's contention that the "statute is one by which it is 'sought to reach the confirmed criminal, whose criminality has been revealed in two serious penal offenses." Id. at 235. The Government's argument here indicates that the rationale of the moral turpitude provision is that conduct reveals characteristics. So viewed, expulsion is not punishment for conduct. But the relevant question is, for what characteristics is expulsion a valid regulatory sanction?

Mr. Justice Jackson argued that the phrase "moral turpitude" was meaningless as a warning, and therefore unconstitutional. He concluded:

We have said that deportation is equivalent to banishment or exile. Deportation pro- 
who one year later authored Harisiades. Leaving aside the inconsistency of Jackson's position, the fact remains that the theory that reasonable notice is necessary in expulsion statutes, accepted by the entire Court in DcGeorge, is incompatible with the rule, confirmed in Harisiades, that the ex post facto clause does not apply to expulsion laws.

\section{Carlson v. Landon: Assumption and Precedent}

The view that the scope of congressional expulsion power vas virtually unlimited was announced explicitly in Carlson $v$. Landon.00 Although the precise issue involved in that case was the validity of the detention of present Communists without bond pending ultimate determination of the right to expel, ${ }^{91} \mathrm{Mr}$. Justice Reed took occasion to expound the majority's conception of the more basic expulsion power: ${ }^{02}$

The basis for the deportation of presently undesirable aliens resident in the United States is not questioned and requires no reexamination. When legally admitted, they have come at the Nation's invitation, as visitors or permanent residents, to share with us the opportunities and satisfactions of our land. As such visitors and foreign nationals they are entitled in their persons and effects to the protection of our laws. So long, however, as aliens fail to obtain and maintain citizenship by naturalization, they remain subject to the plenary power of Congress to expel them under the sovereign right to determine what noncitizens shall be permitted to remain within our borders.93

But if the previous analysis is correct, none of the six cases cited ${ }^{01}$ in support of these principles supports the conclusions asserted. Ekin involved the

ceedings technically are not criminal; but practically they are for they extend the criminal process of sentencing to include on the same convictions an additional punishment of deportation. ... [Thus, the instant alien] is about to begin a life sentence of exile from what has become home, of separation from his established means of livelihood for himself and his family of American citizens. This is a savage penalty. ...

Id. at 243 .

90. 342 U.S. 524 (1952).

91. Pursuant to Act of Feb. 5, 1917, ch. $29, \S 20,39$ Stat. 890-91, as amended, Internal Security Act, ch. 1024, § 23, 64 Stat. 1010-1012 (1950).

92. A contention that the power to expel was lacking was the basis of Mr. Justice Douglas' brief dissent. 342 U.S. at 568-69. The objections of the petitioners were not addressed to the power to expel per se, but raised the question of the effect of this exercise of the power on their constitutional rights under the first, fifth, and eighth Amendments. See id. at $529 \mathrm{nn} .9,10$.

93. Id. at 534 .

94. United States ex rel. Eichenlaub v. Shaughnessy, 338 U.S. 521 (1950); United States v. Curtiss-Wright Export Corp., 299 U.S. 304 (1936) ; Ng Fung Ho v. White, 259 U.S. 276 (1922); Bugajewitz v. Adams, 228 U.S. 585 (1913); Fong Yue Ting v. United States, 149 U.S. 698 (1893) ; Nishimura Ekiu v. United States, 142 U.S. 651 (1892). Also cited was 3 Hackworte, Digest of International. Law 725 (1942). 
power to exclude, and first enunciated the conditional-entry theory of expulsion ;85 Fong Yue Ting, despite its broad language, does not support, either on its facts or upon an analysis of the opinion, unlimited power to expel;00 Bugajezritz concerned the ejection of an erroneously admitted alien ${ }^{07} \mathrm{Ng}$ Fung $H o$ involved the power to eject illegal entrants; 98 Curtiss-Wright did not involve the power to expel, and merely noted that the power to expel, as it affects external relations, is inherent in sovereignty; $; 0$ finally, Eichenlanb not only did not consider any constitutional issues, but involved expulsion for wartime criminal activity. ${ }^{100}$ Thus it seems clear that, while the basic power to expel may have been unquestioned by the petitioners in Carlson, the constitutional issue was one for initial examination, rather than reexamination.

Mr. Justice Reed's attempted justification of his position disclosed further weaknesses. $\mathrm{He}$ continued:

We have no doubt that the doctrines and practices of Communism clearly enough teach the use of force to achieve political control to give constitutional basis, according to any theory of reasonableness or arbitrariness, for Congress to expel known alien Communists under its power to regulate the exclusion, admission and expulsion of aliens. Congress had before it evidence of resident aliens' leadership in Communist domestic activities sufficient to furnish reasonable ground for action against alien resident Communists. The bar against the admission of Communists cannot be differentiated as a matter of power from that against anarchists upheld unanimously half a century ago in the exclusion of Turner. [United States ex rel. Turner v. Williams, 194 U.S. 279 (1904).] Since "[i]t is thoroughly established that Congress has power to order the deportation of aliens whose presence in the country it deems hurtful," [Citing Bugajezritz and the pertinent quotation of that case in $\mathrm{Ng}$ Fung Ho.] the fact that .... [the instant aliens] were made deportable after entry is immaterial. They are deported for what they are now, not for what they were. [Citing Mahler, Eichenlaub, and Harisiades.] Otherwise, when an alien once legally became a denizen of this country he could not be deported for any reason of which he had not been forewarned at the time of entry. Mankind is not vouchsafed sufficient foresight to justify requiring a country to permit its continuous occupation in peace or war by legally admitted aliens, even though they never violate the laws in effect at their entry. ${ }^{101}$

Initially, it should be noted that the argument based on the danger posed by long-term resident alien Communists might have been relevant in a case involving an attempted exercise of the war power, but it had little to do with the power to regulate admission and exclusion of aliens, from which the

95. See Hesse, The Pre-1917 Cases 1590-91.

96. See id. at 1591-97.

97. See id. at 1621-25.

98. See text accompanying notes 33-42 supra.

99. See Hesse, The Pre-1917 Cases 1601-02.

100. See id. at 1585 n. 55 .

101. 342 U.S. at 535-37. 
power to expel was originally derived, since the causal connection between initial excludability and postentry conduct was not mentioned. Next, the constitutional status of the aliens before the Court was apparently equated to that of an anarchist who was an illegal entrant, here for a temporary visit, and who had been considered by the Court excludable. ${ }^{102}$ No one would argue that Congress could not exclude Communists; but Reed's disregard of the difference between exclusion and expulsion left a serious gap in his reasoning. Accordingly, to support his approval of the retroactive imposition of expulsion statutes, he started with a debatable construction of language torn from the context of Bugajezrits, and then relied on the only two Supreme Court cases dealing with war power expulsion, plus Harisiades, decided the same day as Carlson.

Furthermore, the fears expressed by Mr. Justice Reed concerning the consequences of accepting a conditional-entry theory of expulsion showed a misunderstanding of the nature of that concept. The conditional-entry theory does not necessarily require that once an alien is admitted lawfully he cannot be expelled except for the breach of express conditions imposed at the time of entry. Rather, the Government has a reasonable time after admittance to determine whether its preliminary decision to admit was erroneous or not. The absence of express statutory conditions at the time of entry is not fatal to the existence of the expulsion power. What is crucial is whether the postentry conduct can be reasonably related to preentry characteristics or conditions. ${ }^{103}$

It might be argued that the result reached in Carlson, which involved present Communists, was correct, while that of Harisiades, which involved ex-Communists, was not. This view is supportable if it could be assumed that the constitutional issues in the two cases were merely questions of congressional power under the war power ${ }^{104}$ or of the applicability of the ex post facto clause. But the language of both cases goes far beyond these considerations and indeed suggests a vaguely defined "sovereign" power to expel, unrestrained by constitutional limits. Thus, both are antithetical to the theory advanced here-that absent conditions which justify invoking the war power, or clear reliance by the alien on his foreign nationality, the power of Congress to expel lawfully admitted, long-term resident aliens can be exercised only against those who were, or can reasonably be presumed to have been, excludable on the basis of preentry characteristics.

102. For a discussion of Turner, see Hesse, The Pre-1917 Cases 1598-99.

103. For example, it is submitted that if Congress found that aliens allowed to enter under existing exclusion laws were developing a dangerous disease, and that the incubation period of the disease was such that it could be inferred that any alien showing symptoms within six months after entry had contracted the disease abroad, Congress could act to expel aliens developing the disease within six months of entry regardless of the nature of the exclusionary laws at time of entry.

104. Compare Hesse, The Pre-1917 Cases 1585 n.57. 


\section{Harisiades v. Shaughnessy: Precedent Versus Predilection}

On the issue of substantive limits to the expulsion power, Carlson is neither persuasive nor decisive. The constitutional views expressed must stand or fall with the merits of Harisiades. ${ }^{105}$ The facts of the three cases involved in Harisiades compellingly presented the issues involved in banishment. Each alien had entered as a youth, two at thirteen, one at sixteen, in 1914, 1916, and 1920 respectively. They had, therefore, resided here for 26,30 , and 32 years before arrest in $1946 .^{106}$ Expulsion was sought under the provisions of the Alien Registration Act of $1940^{107}$ making past membership in undesirable political organizations a ground for expulsion. Obviously, the applicability of the ex post facto clause was a crucial question, and one on which the petitioners based their attack. ${ }^{108}$ But the more fundamental issue of the right to remain as a consequence of lengthy residence and family ties was also raised. ${ }^{100}$ This was the first issue considered by the majority opinion of Mr. Justice Jackson.

At the very outset, the opinion confounded the issues presented in the case before the Court and those that had been decided in prior opinions. Thus Jackson began:

These aliens ask us to forbid their expulsion by a departure from the long-accepted application to such cases of the Fifth Amendment provision that no person shall be deprived of life, liberty or property without due process of law. Their basic contention is that admission for permanent residence confers a "vested right" on the alien, equal to that of the citizen, to remain within the country, and that the alien is entitled to constitutional protection in that matter to the same exent as the citizen. Their second line of defense is that if any power to deport domiciled aliens exists it is so dispersed that the judiciary must concur in the grounds for its exercise to the extent of finding them reasonable. The argument goes to the contention that the grounds prescribed by the Act of 1940 bear no reasonable relation to protection of legitimate interests of the United States and concludes that the Act should be declared invalid. Admittedly these propositions are not founded in precedents of this Court. ${ }^{110}$

Since the question raised concerned substantive due process, while prior precedent had considered questions of procedural due process, there was in fact no "long accepted application" of the due process clause to overturn in order to uphold the right of long-term residents to remain. Moreover, while it was

105. Harisiades v. Shaughnessy, 342 U.S. 580 (1952).

106. Id. at 581-83.

107. Ch. 439,54 Stat. 670 . Portions of this act are still in force but the deportation provisions are now found, with some changes, in the Immigration and Nationality Act of 1952, § 241, 66 Stat. 204-08, 8 U.S.C. § 1251. (1958).

108. 342 U.S. at 584.

109. Ibid. The aliens further contended that their first amendment rights were abridged by expulsion. Ibid.

110. Id. at 584-85. 
true that no direct precedent applied substantive due process concepts to expulsion, ${ }^{111}$ Keller ${ }^{112}$ supported the aliens' position in principle. ${ }^{113}$

Having in effect assumed the conclusion ultimately reached, the opinion continued by arguing that the petitioners, while enjoying the benefits of United States residence, had chosen not to accept citizenship but instead had "prolonged" their original nationalities. ${ }^{114}$ The unexpressed conclusion of this argument, when analyzed, is found to rest on unestablished premises. To be sure, naturalization immunizes a foreign-born person from expulsion, unless he is subsequently denaturalized. ${ }^{115}$ However, the converse of that rule, that the power to expel exists in the absence of naturalization, does not necessarily have to follow constitutionally in all cases. Not only is such a position inhumane, ${ }^{116}$ but it seems to assume that the alien has deliberately chosen foreign allegiance. Indeed, seeking naturalization may precipitate expulsion proceedings. ${ }^{117}$ To adopt the position that failure to become naturalized places the resident alien indefinitely in the danger of being expellable merely assumes

111. There was, however, MIr. Justice Murphy's concurring opinion in Bridges $v$. Wixon, 326 U.S. 135, 157-66 (1945). See also Mrr. Justice Harlan's views in Lem Aloon Sing v. United States, 158 U.S. 538, 547-48 (1895), quoted in Hesse, The Pre-1917 Cases 1613 n.214.

112. Keller v. United States, 213 U.S. 138 (1909).

113. See Hesse, The Pre-1917 Cases 1605-09.

114. 342 U.S. at 585.

1.15. See, e.g., United States $e x$ rel. Eichenlaub v. Shaughnessy, 338 U.S. 521 (1950).

116. Compare U.S. President's Congar's on Inssigration and Naturalizatio:; Report-Whour We Shail Welcose 193 (1953) [hercinafter cited as Presidenit's Cosss's REP.] :

It will be agreed, so long as the law permits aliens to remain in this country without time limit, that a moral, if not a legal, obligation exists to treat such people fairly. Especially where, as in this country, the alien is permitted to become a full-fledged member of the community in which he lives; to be employed, to own property, to marry and raise a family, to pay taxes, to serve in the armed forces, and otherwise to participate in all activities save those reserved for citizens, such as voting.

117. This was the case in Harisiades. Committee on Immigration and Naturalization, Political Deportations in the United States, 14 Law. Gumb Rev. 93, 122 n.260 (1954). See also Kessler v. Strecker, 307 U.S. 22, 23-24 (1939) ; Latva v. Nicolls, 106 F. Supp. 658 (D. Mass. 1952). Fifty-three of the 320 expulsion cases studied by the Common Council for American Unity "came to the attention of the Service through an application [for naturalization] filed by the alien himself." Lowenstern, The AIten aNd tHe Iararsaration Law 165 (1957).

An ex-Communist is eligible to become naturalized if his membership antedates the application by at least ten years. Immigration and Nationality Act of 1952, $\S 313(\mathrm{c}), 66$ Stat. 241, 8 U.S.C. $\& 1424$ (c) (1958). Of the 254 post-1950 political expulsion cases from which information was available, 173 had tried to become citizens before expulsion proceedings were initiated, 78 of which were pending at the time of arrest; 1 was unable to apply for citizenship because of nationality; 9 had been citizens but lost citizenship because of denaturalization, marriage to an alien, and on other grounds; 5 had believed that they were citizens by birth, marriage, or derivation; only 66 had made no effort to achicve citizenship. Appendix to Brief for Petitioner, p. 8 (table 10), Rowoldt v. Perfetto, 355 U.S. 115 (1957) [hereinafter cited as Rowoldt Appendix]. 
the conclusion desired by the Government. Lengthy residence and family ties with citizens, as well as the possibility that the Constitution might recognize a third, intermediate status, roughly analogous to a denizen at common law, ${ }^{118}$ were ignored.

Finally, the failure to become naturalized does not necessarily assure a continuance of the original nationality or status. ${ }^{110}$ This fact is demonstrated by the nondeportable alien, a status which has been recognized by Congress. ${ }^{120}$ Nevertheless, presuming as a matter of law that foreign allegiance contintted, Mr. Justice Jackson then assumed the existence of special rights of aliens based upon it:

So long as one thus perpetuates a dual status as an American inhabitant but foreign citizen, he may derive advantages from two sources of lawAmerican and international. He may claim protection against our Government unavailable to the citizen. As an alien he retains a claim upon the state of his citizenship to diplomatic intervention on his behalf, a patronage often of considerable value. The state of origin of each of these aliens could presently enter diplomatic remonstrance against these deportations if they were inconsistent with international law, the prevailing custom among nations or their own practices. ${ }^{121}$

The speculative nature of the foregoing arguments is obvious. The possibility of diplomatic intervention is premised on the alien's retention and reliance on his former nationality or status, a premise unreal precisely because when an

118. The status of denizen, midway between that of an alien and a native-born subject, was accorded to aliens who obtained letters patent which the Crown could grant as a matter of royal prerogative. A denizen could take land by purchase or devise, which an alien could not, but was subject to some of the same disabilities, such as exclusion from public office. 1 Blackstone, Commentaries *375.

Under an early South Carolina statute, an alien resident, upon taking an oath of allegiance before a judge, could be deemed a denizen so as to enable him to purchase and hold real property. See McClenaghan v. McClenaghan, 1 Strob. Eq. 295, 298, 47 Am. Dec. 532 (S.C. 1846).

119. Glaring evidence that lengthy residence in this country may render one stateless if he is banished is the case of Mezei, who, after a temporary visit abroad was cxcluded. Shaughnessy v. United States $e x r e l$. Mezei, 345 U.S. 206 (1953). He was unable to find any nation willing to accept him. As a consequence he was incarcerated on Ellis Island for four years before, as an act of executive grace, he was released. See Trop v. Dulles, 356 U.S. 86, 102 n.36 (1958).

120. See, e.g., Act of July 18, 1950, ch. 464,64 Stat. 343. See also H.R. REp. No. 1192, 81st Cong., 1st Sess. 7-12 (1949). The very terms of Immigration and Nationality Act of 1952 , \& 242 (d), 66 Stat. 211, as amended, 8 U.S.C. $\$ 1252$ (d) (1958), are predicated on the existence of nonexpellable aliens. See United States v. Witkovich, 353 U.S. 194, 201 (1957).

Of 219 cases involving political expulsions between 1944-1952, 40\% were not expellable to their countries of nativity. Committee on Immigration and Naturalization, Political Dcportations in the United States, 14 LAw. Guild REv. 93, 112 (1954). Of the 254 post-1950 cases for whom facts were known, in 105 cases the place of birth had become part of a different country. See Rowoldt Appendix 9 (table 11). The Attorney General has likewise recognized the fact that expulsion to certain countries is impossible. 1955 ATr'Y GEN. ANN. REP. 408.

121. 342 U.S. at 585-86. 
alien becomes permanently domiciled in another country, thereby avoiding the responsibilities of his former nationality, he forfeits the right to seek diplomatic protection. ${ }^{122}$ By residing here permanently, and by seeking the protection of his constitutional rights as an American resident, the alien probably waives whatever rights he might enjoy under international law. ${ }^{123} \mathrm{~A}$ noncitizen seeking constitutional protection is not, therefore, as seems to be implied, reprehensibly seeking to invoke the more protective of two sets of rights. But, even if he were, such a consideration is irrelevant since the constitutional guarantee of due process applies expressly to persons, not merely to citizens. Besides, if it is true, as the opinion later asserted, that under in. ternational law every sovereign nation has the right to expel undesirable aliens, the imagined diplomatic protection is completely illusory, for apparently there would be no grounds for complaint as long as procedural proprieties were observed.

The alien's immunities from military service in certain circumstances were also urged as a reason for denying immunity from expulsion even to longterm residents. ${ }^{124}$ This argument likewise seems fallacious. It is arguable that the immunity from certain duties is offset by the withholding of rights other than the right to remain, such as the passport and the vote. But more telling is the fact that permanent resident aliens are in reality not entirely free from the duties of citizenship, ${ }^{125}$ even including the bearing of arms. ${ }^{120}$ The resident alien's only "immunity" in this respect appears to be Jackson's recognition that he is not ordinarily compelled to engage in war against his native country. ${ }^{127}$ But it would seem that refusal to do so would be an act of reliance

122. See Borchard, Diplodatic Protection of Citizens Abrond $810-11$ (1915) [hereinafter cited as BoRchaRd].

"The Court's emphasis on the theoretical advantages of the dual national connection of the resident alien loses much of its appeal when measured realistically against the alien's inability to secure benefits from a country he had abandoned, perinaps in flight, many years before" The Supreme Court, 1951 Term, 66 HARv. L. REv. 89, 106 (1952).

123. Compare BoRCEARD 731-32 (U.S. native's evading the duties of citizenship during long residence abroad is basis for denying diplomatic protection).

124. $3 \div 2$ U.S. at 586 .

125. See Lau Ow Bew v. United States, 144 U.S. 47, 61-62 (1892).

126. The Selective Service Act of 1948, as amended, provides that, "except as otherwise provided ... every male alien admitted for permanent residence, who is between the ages of 18 years and 6 months and 26 years ... shall be liable for training and service in the Armed Forces of the United States . . ." 65 Stat. 76 (1951), as amended, 50 U.S.C. $\$ 454$ (a) (Supp. V, 1958). Congress has, moreover, expressly indicated that permanent residents should expect to assume the duty of military service. See S. REP. No. 1515, 81st Cong., 2d Sess. 354 (1950).

Failure to perform the duty of bearing arms subjects one to subsequent exclusion, as an alien ineligible to citizenship, Immigration and Nationality Act of 1952, $\S \S 101$ (a) (19), 212 (a) (22), 66 Stat. 169, 184, 8 U.S.C. $\$ \$ 1101$ (a) (19), 1182 (a) (22) (1958). Such conduct also makes the alien deportable. Immigration and Nationality Act of $1952, \$ 241$ (a) (1), 66 Stat. 204, 8 U.S.C. § 1251 (a) (1) (1958).

127. See Johnson v. Eisentrager, 339 U.S. 763, 773 (1950). 
on his former nationality, and a consequent rejection of the status of an American resident. Besides, being an "enemy alien" under such circumstances, he can be interned and removed. ${ }^{128}$ The "right" not to engage in war under such circumstances seems totally irrelevant to the question of the constitutional status of the resident alien seeking to avoid banishment in time of peace, and the making of such an argument merely provides one more piece of evidence of the uncritical homogenization of peacetime and wartime powers.

Mr. Justice Jackson also found it significant that aliens "may enjoy particular treaty privileges," 129 once again indicating a failure to appreciate the distinction between aliens who rely on their American residence and those who rely on their foreign nationality. It is true that treaties may affect the right of noncitizens to enter and remain here, ${ }^{130}$ but in such cases there is no basis for claiming protection as an American resident. This fact distinguishes the early cases dealing with Chinese laborers, who sought protection under international law as subjects of China entitled to special treaty rights, a position which occasioned the Court's initial discussion of the power of sovereign nations to exclude and expel irrespective of any express constitutional delegation of power. ${ }^{131}$ But the modern immigrant, who enters under the domestic immigration laws regulating foreign commerce, would seem to be in an entirely different constitutional category. ${ }^{132}$

On the basis of the foregoing questionable rationale, Mr. Justice Jackson then considered the basic question of constitutional power to banish:

Under our law, the alien in several respects stands on an equal footing with citizens, $\ldots .^{133}$ but in others has never been conceded legal

128. Enemy Alien Act of 1798 , ch. 66,1 Stat. 577, codified in REv. STAT. $\$ \$ 4067-70$ (1875), as amended, 50 U.S.C. $\$ \$ 21-24$ (1952).

129. The opinion's only citation on this point is BorCeARD 64, which deals with the issue of military exemption under treaty. Of course, reliance on such a privilege negatives any right to rely on one's domicil here.

130. See Karnuth v. United States, 279 U.S. 231 (1929). Compare Cheung Sum Shee v. Nagle, 268 U.S. 336, 345 (1925), with Chang Chan v. Nagle, 268 U.S. 346, 351 (1925).

131. See Fong Yue Ting v. United States, 149 U.S. 698 (1893); Chae Chan Ping v. United States (The Chinese Exclusion Case), 130 U.S. 581 (1889); Hesse, The Pre-1917 Cases 1588-89, 1592.

132. Since 1924, before a potential immigrant departs for our country, he must express an intent to become a permanent resident. Such an alien is admitted pursuant to the gelleral immigration laws if qualitatively acceptable, and not pursuant to a treaty. Thus, the reasoning of Chae Chan Ping and Fong Yue Ting, both supra note 131, is neither applicable nor persuasive. See Boudin, The Settler Within Our Gates-III, 26 N.Y.U.L. Rev. 634, 649-50 (1951.).

133. The omitted citations, in the order cited, were Yick Wo v. Hopkins, 118 U.S. 356, 369 (1886) (licensing ordinance cannot discriminate against alien); Truax v. Raich, 239 U.S. 33 (1915) (state statute limiting number of aliens who could be employed in given place of business held to violate equal protection clause); Nishimura Ekiu v. United States, 142 U.S. 651 (1892) (right to habeas corpus) ; Wong Wing v. United States, 163 U.S. 228 (1896) (alien cannot be subjected to criminal penalties without following criminal procedure) ; and Russian Volunteer Fleet v. United States, 282 U.S. 481 (1931) (property of friendly alien corporation cannot be seized without compensation). 
parity with the citizen. Most importantly, to protract this ambiguous status within the country is not his right but is a matter of permission and tolerance. The Government's power to terminate its hospitality has been asserted and sustained by this Court since the question first arose. ${ }^{13 s}$

The implicit assumption underlying the entire opinion was finally stated explicitly: constitutionally, permanent residence short of naturalization is merely temporary residence. ${ }^{135}$ Stating the proposition in such terms reveals its paradoxical nature. Moreover, just as in Carlson, none of the cases cited to support this view ${ }^{130}$ involved the power to banish the long-term, lawfully admitted resident. Three did not involve expulsions at all; $;$ three others involved at most the ejection of short-term residents either actually or presumptively excludable at entry. ${ }^{138}$ And, of these six, four were concerned with Orientals who were racially ineligible for naturalization and who were originally considered nonassimilable almost as a matter of law. ${ }^{130}$ The cases most nearly in point, Bugajezritz and Fong Yuc Ting, when analyzed, also fail to support Mr. Justice Jackson's position, since both can be understood to have involved aliens who could not show that they had not been excludable at time of entry. ${ }^{140}$ As examples of the termination of the Government's hospitality, the cases cited may have relevance, but as binding authority for banishment in an era when manner and time of entry are provable as a matter of course, they are insufficient.

The opinion's remaining discussion of the substantive due process argument merely expands upon its uncritical downgrading of the status of the long-term lawfully admitted resident to that of the illegal and erroneously admitted

134. 342 U.S. at $586-87$.

135. But cf. Case of Fries, 9 Fed. Cas. 826 (No. 5126) (C.C.D. Pa. 1799). Compare Johnson v. Eisentrager, 339 U.S. 763, 770 (1950) (reference to "probationary residence" of aliens). See also Hesse, The Pre-1917 Cases $1597 \mathrm{n} .123$ (discussing possibility that Fong Yue Ting v. United States, 149 U.S. 698 (1893), could be read to mean that Chinese aliens were then temporary residents as a matter of law).

136. Bugajewitz v. Adams, 228 U.S. 585 (1913); Tiaco v. Forbes, 228 U.S. 549 (1913) ; Zakonaite v. Wolf, 226 U.S. 272 (1912); United States v. Ju Toy, 198 U.S. 253 (1905); The Japanese Immigrant Case, 189 U.S. 86 (1903) ; Folk Yung Yo v. United States, 185 U.S. 296 (1902); Li Sing v. United States, 180 U.S. 486 (1901); Lem MIoon Sing v. United States, 158 U.S. 538 (1895); Fong Yue Ting v. United States, 149 U.S. 698 (1893).

137. United States v. Ju Toy (procedural propriety of administrative determination of entrant's claim of citizenship); Fok Yung Yo v. United States (power to prohibit transit through United States); Lem Moon Sing v. United States (exclusion upon reentry), all supra note 136.

138. Zakonaite v. Wolf, 226 U.S. 272 (1912); The Japanese Immigrant Case, 189 U.S. 86 (1903) ; Li Sing v. United States, 180 U.S. 486 (1901).

139. See Chae Chan Ping v. United States (The Chinese Exclusion Case), 130 U.S. 581,595 (1889).

140. See Hesse, The Pre-1917 Cases 1591-97, 1621-25.

The only other case cited by Jackson was Tiaco v. Forbes, 228 U.S. 549 (1913), which does not support congressional power to banish. See Hesse, stpra at 1619-21. 
aliens. But because of the confusion disclosed with respect to the prior holdings regarding the source of the power to expel, its contents require further examination. Citing the power over enemy aliens in time of war, the opinion continued:

But it does not require war to bring the power of deportation into existence or to authorize its exercise. Congressional apprehension of foreign or internal dangers short of war may lead to its use. So long as the alien elects to continue the ambiguity of his allegiance his domicile here is held by a precarious tenure.

That aliens remain vulnerable to expulsions after long residence is a practice that bristles with severities. But it is a weapon of defense and reprisal confirmed by international law as a power inherent in every sovereign state. ${ }^{141}$ Such is the traditional power of the Nation over the alien and we leave the law on the subject as we find it. ${ }^{142}$

Thus, the atmosphere that had pervaded Chae Chan Ping ${ }^{143}$ was resurrected; war and peacetime power were confounded. This failure to differentiate between the different constitutional powers involved in wartime and peacetime expulsion almost seems to have led Mr. Justice Jackson to the implicit assertion of a national police power over aliens. He failed to recognize that, in situations not justifying the use of the war power, the power to expel might be connected with the power to regulate foreign commerce. In this respect, both the Carlson and Harisiades opinions represent an unstated rejection rather than observance of precedent. The cases which first discussed the doctrine of inherent sovereignty did so in regard to an entirely different issuethe power to expel despite treaties with other nations concerning entering or resident aliens. With respect to the power under domestic law, however, the constitutionally delegated sources of the expulsion power were carefully specified. In other words, the power to expel was recognized as a sovereign power which was exercisable only within the constitutional framework. Disposing of the constitutional question of the power over the resident alien on the basis of international law, therefore, did not resolve the issue but avoided it. Rather than leaving the law on the subject undisturbed, Harisiades actually marked a new departure. To be sure, prior to Harisiades there had been wide acceptance of the unlimited power of Congress over the resident alien. But the issue of the extent of the power had not yet been contested.

Moreover, not only did Mr. Justice Jackson ignore the implications of

141. Here primary reliance was placed on international law authorities, which while perhaps not irrelevant, are not decisive of a question concerning domestic constitutional law. The only case cited was, significantly, Fong Yue Ting, which supports such a conclusion with respect to the power of the United States vis-à-vis another nation, but not with respect to direct power over the resident alien since the issue of power over the alien was considered in Fong $Y_{u e}$ Ting in terms of the power delegated by the Constitution. See Hesse, The Pre-1917 Cases 1593-95.

142. 342 U.S. at $587-88$.

143. Chae Chan Ping v. United States (The Chinese Exclusion Case), 130 U.S. 581, 595,606 (1889). 
Keller, but he showed himself to be unfamiliar with the real history of immigration legislation. ${ }^{144}$ Only after the existence of congressional power has been assumed is the question of time limitations within which expulsion must be effectuated mentioned. ${ }^{145}$ Thus, the true nature of the relationship between the power to expel and the power to exclude was submerged, and limitations of time were tested in terms of policy, not power. This resulted in standing history on its head.

The remaining discussion of the due process issue considered whether the Court should interfere with legislative policy, obviously avoiding the issue of upon whom such policies may be imposed. Citing the intricacies of foreign policy, the danger of communist aggression, and the hardships involved in the wartime relocation of citizens of Japanese descent, which the Court had previously approved, ${ }^{146}$ the Court declined to intervene. ${ }^{147}$

The concluding passage in Mr. Justice Jackson's disposal of the substantive due process argument left no doubt that the constitutional rights of resident

144. In an extended footnote, 342 U.S. $588-89 \mathrm{n} .15$, he purported to outline the history of immigration legislation. A careful comparison of the footnote with the various acts concerning aliens discloses many errors. For example, he stated that "Congress, in 1907, provided for deportation of legally resident aliens, but the statute reached only women found engaging in prostitution, and deportation proceedings were authorized only within three years after entry." (Emphasis added.) But the act actually dealt with cxclusion, creating a conclusive presumption of erroneous admittance. See Hesse, The Pre-1917 Cases 1616 \& nn.240-43. Mrr. Justice Jackson thus displayed an unfamiliarity with MIr. Justice Holmes' opinion in Keller, where he wrote: "For the purpose of excluding those who unlawifully enter this country, Congress . . may make their [aliens'] admission conditional." Keller v. United States, 213 U.S. 138, 149-50 (1909) (dissenting opinion). (Emphasis added.) See Hesse, supra at 1605-09. This misunderstanding of the original concept of deportable acts as the basis for a conclusive presumption of erroneous entry undermines the entire opinion.

A substantially accurate survey of the legislation is given in Brief for Mascitti, pp. 1217, Harisiades v. Shaughnessy, 342 U.S. 580 (1952). Although the other errors may perhaps seem inconsequential in themselves, their cumulative impact is disturbing, since it is impossible to appreciate the true import of the early cases, particularly Fong Yine Ting and Bugajeccitz, without fully understanding the legislation involved.

145. 342 U.S. at 588.

146. Ex parte Endo, 323 U.S. 283 (1944) ; Korematsu v. United States, 323 U.S. 214 (1944) ; Hirabayashi v. United States, 320 U.S. 81 (1943).

Despite the extreme hardships imposed by Japanese relocation, upheld on the most debatable grounds, internment is not banishment. MIoreover, the action was upheld solely on the basis of the necessities of war. Harisiades, however, purported to settle the question of peacetime power. On this point, at least, Mr. Justice Jackson would have to plead guilty to Jonathan Swift's indictment:

It is a Maxim among these Lawyers, that whatever hath been done before, may be legally done again: And therefore they take special Care to record all the Decisions formerly made against common Justice and the general Reason of Mankind. These, under the Name of Precedents, they produce as Authorities, to justify the most iniquitous Opinions; and the Judges never fail of directing accordingly.

SwIFT, Gulliver's Travezs 203 (Modern Library ed. 1958).

147. 342 U.S. at 588-91. 
Americans had been watered down to the common denominator of international law. ${ }^{148}$ The opinion stated:

We think that, in the present state of the world, it would be rash and irresponsible to reinterpret our fundamental law to deny or qualify the Government's power of deportation. However desirable world-wide amelioration of the lot of aliens, we think it is peculiarly a subject for international diplomacy. It should not be initiated by judicial decision which can only deprive our own Government of a power of defense and reprisal without obtaining for American citizens abroad any reciprocal privileges or immunities. Reform in this field must be entrusted to the branches of the Government in control of our international relations and treaty-making powers. ${ }^{149}$

Thus the resident alien was held subject to the diplomatic vicissitudes of the cold war. This conclusion seems unavoidable in view of the justification of banishment as an instrument of "defense and reprisal." If this is understood to refer only to the undesirable conduct of the individual alien, then it approaches the recognition of banishment as punishment. Since Mr. Justice Jackson refused to adopt such a view, ${ }^{150}$ however, what he must have meant in the present context was that the power to banish is a necessary weapon in international relations. Under this view, the individual character of the alien resident is ignored and the conduct of the government in power in the country of his nativity or, even worse, the government of still another country, say Russia or Communist China, is allowed to determine his constitutional status. Even assuming that such a view makes any constitutional sense, in practice the principle upon which it is based is aborted. Communist countries will not accept our political rejects. ${ }^{151}$ Of the three aliens involved in Harisiades, one was of Russian nativity, but the others were born in Greece and Italy, ${ }^{152}$ friendly nations, where the deportees, if they currently held dangerous political views, could be just as harmful to the United States as if they remained. Such results are to be expected, however, so long as the power to banish is treated as a political rather than a constitutional question. Political motivations often involve, almost by definition, short-term expediencies. What is needed, instead, is a rational, humane and permanent constitutional policy.

After rejecting summarily the claim that deportation violated the aliens'

148. See Borchard, The "Minimum Standard" of the Treatment of Aliens, 38 Micn.

L. REv. 445 (1940).

149. 342 U.S. at 591.

150. See note 156 infra and accompanying text.

151. See United States v. Spector, 343 U.S. 169, 179-80 (1952) (dissenting opinion of Jackson, J.).

And aliens may not be deported to countries where they would be exccuted or imprisoned. Immigration and Nationality Act of 1952, $\S 243(\mathrm{~h}), 66$ Stat. 214,8 U.S.C. $\S 1253(\mathrm{~h})$ (1958).

152. 342 U.S. at $581-83$. 
first amendment right of free speech, ${ }^{153} \mathrm{Mr}$. Justice Jackson turned to the problem of retroactively making past membership in a class ground for expulsion.

The remaining claim is that this Act conflicts with Art. I, § 9, of the Constitution forbidding $e x$ post facto enactments. An impression of retroactivity results from reading as a new and isolated enactment what is actually a continuation of prior legislation.

During all the years since 1920 Congress has maintained a standing admonition to aliens, on pain of deportation, not to become members of any organization that advocates overthrow of the United States Government by force and violence, a category repeatedly held to include the Communist Party. These aliens violated that prohibition and incurred liability to deportation. They were not caught unawares by a change of law. There can be no contention that they were not adequately forewarned both that their conduct was prohibited and of its consequences. ${ }^{16}$

In denying that the statute as applied involved any practical retroactivity, the opinion ignored the significance of the fact that the "standing admonition" of the 1920 act applied only to present members. ${ }^{105}$ Arguably, the former statute gave notice to aliens that if they abandoned their communist activities, they would not be deported. It did not in itself notify them that Congress reserved the power to change the law so that even a sincere change of heart, made perhaps in reliance on existing law, would later prove to have been of no avail. Thus, the argument here rests on the implicit assumption that Congress has power to vary the deportable classes at will, with no duty to inform an alien that certain conduct will subject him to deportation, while other courses of action remain safe.

That the decision actually rested on these grounds was next made explicit. Resorting to the traditional distinction between criminal and civil penalties, the opinion continued:

However, even if the Act were found to be retroactive, to strike it down would require us to overrule the construction of the e.r post facto provision which has been followed by this Court from earliest times. It always has been considered that that which it forbids is penal legislation which imposes or increases criminal punishment for conduct lawful previous to its enactment. Deportation, however severe its consequences, has

153. 342 U.S. at 591-92. The propriety of this holding, however, is questionable since the opinion relied solely on Dennis v. United States, 341 U.S. 494 (1951), which involved present leaders of the Communist Party. The Court held in Demmis that the then existing circumstances met the test of clear and present danger. Just how the past activities of those involved in Harisiades constituted either a clear or a present danger was not entirely explained. See also United States v. Witkovich, 353 U.S. 194, 201 (1957).

154. 342 U.S. at 593.

155. See Kessier v. Strecker, 307 U.S. 22 (1939). The Supreme Court had recognized that at least as late as 1927, there was some doubt as to whether the Communist Party did in fact advocate the overthrow of the government by force and violence. See Schneiderman v. United States, 320 U.S. 118 (1943). Compare Maisenberg v. United States, 356 U.S. 670 (1958); Nowak v. United States, 356 U.S. 660 (1958). 
been consistently classified as a civil rather than a criminal procedure. Both of these doctrines as original proposals might be debatable, but both have been considered closed for many years and a body of statute and decisional law has been built on them. ${ }^{166}$

Stare decisis is an irrelevant answer to constitutional questions of major import. But the two expulsion cases relied on at this point ${ }^{157}$ did not settle the issue before the Court in any event. Far from precluding the application of the ex post facto clause to expulsion proceedings in general, Bugajervits merely determined that because of erroneous admittance, either actual or presumed, the statute involved had not been retroactively applied. ${ }^{168} \mathrm{Mahlcr}$, on the other hand, did uphold retroactive legislation but it was of a different category, concerned with the removal of aliens convicted of wartime crimes. ${ }^{160}$ A relevant inquiry, moreover, is what had become of the basic assumption underlying the Court's opinion in Jordan $v$. DeGeorge?160 Perhaps it was DeGeorge which compelled Mr. Justice Jackson to argue alternatively that the act was not retroactive in legal effect. For, clearly, the ruling that the ex post facto clause does not apply to expulsion statutes is fundamentally inconsistent with the application of the void-for-vagueness doctrine. If an alien is entitled to reasonably communicative notice as to the consequences of his future acts, then how can the lack of any prior notice be held constitutionally valid?

Mr. Justice Jackson argued further that the earlier cases which had held civil disabilities to be subject to the ex post facto clause involved criminal penalties in civil disguise. But this distinction should only make the applicability of the clause to banishment all the more apparent. For the cases which held that ejection proceedings were not criminal in nature dealt with persons whose status had been obtained erroneously or by fraud, ${ }^{161}$ and thus cannot be validly applied in the banishment situation. That banishment is punishment

156. 342 U.S. at 594. (Footnotes omitted.)

157. Mahler v. Eby, 264 U.S. 32 (1924) ; Bugajewitz v. Adams, 228 U.S. 585 (1913).

158. See Hesse, The Pre-1917 Cases 1623-25.

159. See notes $44-47$ supra and accompanying text.

160. 341 U.S. 223 (1951.).

161. He thus purported to distinguish Fletcher v. Peck, 10 U.S. (6 Cranch) 87 (1810); Cummings v. Missouri, 71 U.S. (4 Wall.) 277 (1867); Ex parte Garland, 71 U.S. (4 Wall.) 333 (1867) ; and Pierce v. Carskadon, 83 U.S. (16 Wall.) 234 (1873), relying on Burgess v. Salmon, 97 U.S. 381, 385 (1878). But how the deprivation of the right to act as a priest (Cummings), to practice law (Garland), or to enjoy access to state courts (Carskadon), by means of an expurgatory oath concerning past confederate activities is more of a criminal sanction than expulsion of a long term resident alien for past political activities is not explained. See Speiser v. Randall, 357 U.S. 513 (1958) which, in effect, restated the theory of Cummings and Garland in procedural due process terms. Morcover, Burgess in fact followed rather than distinguished the earlier cases, indicating that the retroactive imposition of an additional tax would violate the ex post facto clause. But cf. Helvering v. Mitchell, 303 U.S. 391 (1938). The expulsion cases are collected by Mr. Justice Brandeis in id. at 399 n.2. Compare ibid. with Hesse, The Pre-1917 Cases 1592-93, 1618-19, 1623-25. 
had, moreover, been emphatically recognized by Mr. Justice Jackson only the year before in DeGeorge. ${ }^{\mathbf{1 6 2}}$

Finally, the conclusion of the opinion disclaimed any constitutional necessity of recognizing the possibility of reformation when past conduct is all that supports the expulsion, asserting that:

When the Communist Party as a matter of party strategy formally expelled alien members en masse, it destroyed any significance that discontinued membership might otherwise have as indication of a change of heart by the individual. Congress may have believed that the party tactics threw upon the Government an almost impossible burden if it attempted to separate those who sincerely renounced Communist principles of force and violence from those who left the party the better to serve it. Congress, exercising the wide discretion that it alone has in these matters, declined to accept that as the Government's burden. ${ }^{103}$

Judicial relief was thus denied on the basis of conduct of third parties over whom the aliens could probably exercise no control. Admittedly, difficulty of proof was the motivating factor behind the early provisions substituting proof of postentry conduct for proof of initial excludability. But under those provisions the undesirable conduct which gave rise to the presumption was that of the alien himself. In the present argument, however, difficulty of proof was said to justify setting up an irrebutable presumption of present undesirability based on past conduct, a process which in itself seems questionable. ${ }^{104}$ As applied here, however, the process went even further, for in effect, the presumptions were pyramided: presumed excludability being established by presumed character.

Taken together, Carlson and Harisiades marked a decisive departure in American law. Nonetheless, while Harisiades attempted to put the question of power to banish beyond debate, it has not been accepted by the Court as the final word on the subject.

\section{Galvan v. Press: Precedent as a System of Morals}

The validity of the provisions of the Internal Security Act of 1950,105 which eliminated the necessity of proving that the Communist Party advocated over-

162. 341 U.S. at 243 (dissenting opinion).

163. 342 U.S. at 595-96. This argument was made in the face of the fact that Corlson, decided the same day, involved present members of the Communist Party. See notes 91104 supra and accompanying text.

164. As authority for the power to deport under international law the Court [in Harisiades] cited 1 Oppenmem, International LaW 498 (3d ed., Rosburgh, 1920) and 4 MOORE, INTERNatToNal LAw Digest 67-96 (1906). However, a widely quoted corollary to this power is the requirement that determination of undesirability be made in each case. See 1 Hyde, International Law 230-31 (2d rev. ed. 1945); Borchard, Diplomattc Protection of Citizens abro.so 50-51 (1915).

The Supreme Court, 1951 Term, 66 Hanv. L. REv. \$9, 105 n.44 (1952). Compare Mahhler v. Eby, 264 U.S. 32 (1924).

165. Ch. 1024, \& 22, 64 Stat 1006-1010 (now incorporated in seattered sections of Immigration and Nationality Act of 1952, 66 Stat. 163, 8 U.S.C. $\$ \S 1101-1503$ (1952)). 
throw of the government by force and violence, was questioned in Galvan $v$. Press. ${ }^{106}$ The case involved an American resident who had first entered in 1918 and had "since resided here with only occasional brief visits to his native country [Mexico]." $167 \mathrm{He}$ contended that to deport him without giving him an opportunity to prove that he had not been aware of the party's principles denied him due process of law. ${ }^{168}$ The opinion of Mr. Justice Frankfurter assumed an understanding approach to the substantive due process argument.

[C]onsidering what it means to deport an alien who legally became part of the American community, and the extent to which, since he is a "person," an alien has the same protection for his life, liberty and property under the Due Process Clause as is afforded to a citizen, deportation without permitting the alien to prove that he was unaware of the Communist Party's advocacy of violence strikes one with a sense of harsh incongruity. If due process bars Congress from enactments that shock the sense of fair play-which is the essence of due process-one is entitled to ask whether it is not beyond the power of Congress to cleport an alien who was duped into joining the Communist Party, particularly when his conduct antedated the enactment of the legislation under which his deportation is sought. And this because deportation may, as this Court has said in $\mathrm{Ng}$ Fung Ho v. White, 259 U.S. 276, 284, deprive a man "of all that makes life worth living"; and, as it has said in Fong Haw Tan v. Phelan, 333 U.S. 6, 10, "deportation is a drastic measure and at times the equivalent of banishment or exile."

In light of the expansion of the concept of substantive due process as a limitation upon all powers of Congress, even the war power, see Hamilton v. Kentucky Distilleries \& Warehouse Co., 251 U.S. 146, 155, much could be said for the view, were we writing on a clean slate, that the Due Process Clause qualifies the scope of political discretion heretofore recognized as belonging to Congress in regulating the entry and deportation of aliens. And since the intrinsic consequences of deportation are so close to punishment for crime, it might fairly be said also that the ex post facto Clause, even though applicable only to punitive legislation, should be applied to deportation. ${ }^{160}$

Although the tone was decidedly different from Harisiades, clearly the conclusion was to be the same. Mr. Justice Frankfurter equally assumed that Congress had unlimited discretion to designate undesirable classes of aliens and to deport members of those classes. No new awareness of the actual legislative or judicial history of immigration law was displayed. In fact, although recognizing the existence of compelling considerations which might well have led to the jettisoning of any precedent, including Harisiades, which indicated that congressional power was unlimited in scope, the opinion instead appealed to an erroneous interpretation of history to support exactly that conclusion.

But the slate is not clean. As to the extent of the power of Congress under review, there is not merely "a page of history," Nezw York Trust

166. 347 U.S. 522 (1954).

167. Id. at 523 .

168. Id. at 530 .

169. Id. at $530-31$. 
Co. v. Eisner, 256 U.S. 345, 349, but a whole volume. Policies pertaining to the entry of aliens and their right to remain here are peculiarly concerned with the political conduct of government. In the enforcement of these policies, the Executive Branch of the Government must respect the procedural safeguards of due process. The Japanese Immigrant Case, 189 U.S. 86, 101; Wong Yang Sung v. MIcGrath, 339 U.S. 33, 49. But that the formulation of these policies is entrusted exclusively to Congress has become about as firmly imbedded in the legislative and judicial tissues of our body politic as any aspect of our government. And whatever might have been said at an earlier date for applying the e.r post facto Clause, it has been the unbroken rule of this Court that it has no application to deportation.

We are not prepared to deem ourselves wiser or more sensitive to human rights than our predecessors, especially those who have been most zealous in protecting civil liberties under the Constitution, and must therefore under our constitutional system recognize congressional power in dealing with aliens, on the basis of which we are unable to find the Act of 1950 unconstitutional. See Bugajewitz v. Adams, 228 U.S. 585, and $\mathrm{Ng}$ Fung Ho v. White, 259 U.S. 276, 280.170

This argument is a glaring example of the inherent dangers of applying the doctrine of stare decisis to constitutional questions. ${ }^{171}$ What was decided in the past does not necessarily have direct relevance to the human problems of today. Precedent may suggest earlier views of those faced with analogous or similar problems, but "an expression in an opinion yields later to the impact of facts unforeseen."172 When thought becomes crystallized as dogma, however, reliance is too readily placed on words rather than thought. Thus, Galvan discarded the fate of thousands of human beings, not on the basis of past thought, but on present interpretations of past texts. The slate may have been dirty by the time Mr. Justice Frankfurter considered it, but it was the gloss of recent judges which had rendered it illegible and totally divorced from the human realities involved.

Thus, the attempt to place the blame for the failure to end the concededly inhuman consequences of according absolute power to Congress on the shoulders of Mr. Justice Holmes and Mr. Justice Brandeis ("those who have been most zealous in protecting civil liberties") was made doubly objectionable by the misconception of the precedents which such an attempt revealed.173 $\mathrm{Ng}$ Fung $\mathrm{Ho}$ involved the ejection of illegal entrants, Bugajewit $z$ the ejection

170. Id. at 531-32.

171. It is appropriate to note Mr. Justice Frankfurter's subsequent recognition that blindly following precedent is not permissible "especially . . . in constitutional controversies." Reid v. Covert, 354 U.S. 1, 51 (concurring opinion).

172. Jaybird Mining Co. v. Weir, 271 U.S. 609, 619 (1926) (dissenting opinion of Brandeis, J.).

173. Compare Harisiades v. Shaughnessy, 342 U.S. 580, 597 (1952) (concurring opinion of Frankfurter, J.). In Latva v. Nicolls, 106 F. Supp. 658, 660 (D. Afass. 1952), Judge Wyzanski pointed out that the majority opinion in Harisiades left room for some substantive due process limitations on congressional power over aliens, but cited Frankfurter's concurrence as possible authority for an opposite view. 
of an erroneously admitted resident; none of the aliens concerned had resided here more than five years. The human issues involved in those cases were vastly different from those presented in Galvan. In fact, Mr. Justice Holmes, in his opinion in Keller, had expressly conceded to Congress only limited control over the postentry conduct of resident aliens. ${ }^{174}$

\section{A Constitutional Theory of the Immigration Power}

The rational study of law is still to a large extent the study of history. History must be a part of the study, because without it we cannot know the precise scope of rules which it is our business to know. It is a part of the rational study, because it is the first stcp toward an enlightened scepticism, that is, toward a deliberate reconsideration of the worth of those rules. When you get the dragon out of his cave on to the plain and in the daylight, you can count his teeth and claws, and see just what is his strength. But to get him out is only the first step. The next is either to kill him, or to tame him and make him a useful animal. Mr. Justice Holmes ${ }^{176}$

Since the inhumanity of banishment was recognized in Galvan, which was justified solely on misconceived precedent, a fresh consideration of the constitutional basis of the expulsion power is both permissible and desirable. ${ }^{170}$ What is urged is not a radical new theoretical departure, but rather a reexamination of the implications of the conditional-entry theory. Under this theory, the power to expel is an adjunct of the power to exclude, which in turn is derived primarily from the power to regulate foreign commerce. ${ }^{177}$ The expulsion power is thus inherently limited by the requirement that its exercise-except perhaps in situations justifying the use of the war power or where there is clear reliance on foreign nationality-be reasonably related to the regulation of new immigration.

Thus, Congress clearly possesses the power to eject. In the words of $\mathrm{Mr}$. Justice Holmes:

174. Keller v. United States, 213 U.S. 138, 149-50 (1909) (dissenting opinion). Morcover, Keller involved a conclusive presumption of past undesirability on the basis of admittedly undesirable present conduct, which is far less objectionable than a conclusive presumption of present undesirability predicated on ambiguous past conduct, upheld in Galvan.

175. Holmes, The Path of the Law, 10 Harv. L. Rev. 457, 469 (1897).

176. In Rowoldt v. Perfetto, 355 U.S. 115 (1957), banishment was avoided by questionable statutory construction, but Galzan was not overruled. In Latva v. Nicolls, $106 \mathrm{~F}$. Supp. 658,665 n. (D. Mass. 1952), banishment was avoided by an act of executive grace on the part of the Attorney General. Such isolated incidents are not substitutes for the application of appropriate constitutional safeguards.

Furthermore, failure to provide safeguards for the alien may result in the battle against banishment being fought in connection with the rights of the denationalized native born. See Perez v. Brownell, 356 U.S. 44, 65 n.6 (1958) (dissenting opinion of Warren, C.J.); Trop v. Dulles, 356 U.S. 86, 101-02 (1958). See generally Comment, 64 YALE L.J. 1164 (1955).

177. See Hesse, The Pre-1917 Cases 1582-1609. Compare Perez v. Brownell, 356 U.S. 44, 65 n.6 (1958) (dissenting opinion of Warren, C.J.). 
Congress may require, as a condition of the right to remain, good behavior for a certain time, in matters deemed by it important to the public welfare and of a kind that indicates a preexisting habit that would have excluded the party if it had been known. ${ }^{178}$

When an expulsion is based on preentry characteristics, it bears an obvious relationship to foreign commerce. The alien with whom ejection deals is another country's problem, the product of a foreign society. Expulsion of such an alien can be said to be a necessary and proper measure designed to relieve this country of the burdens which might follow an erroneous decision to admit him.

But there comes a point in time after which the alien's conduct can no longer be reasonably related to his preentry characteristics. The various economic and social forces of our society have molded him to the extent that he can no longer be regarded as a foreign product. The expulsion of such a person, which is here termed banishment, cannot reasonably be regarded as a regulation of immigration. It is an attempt to deal with our own internal problems, to control the conduct of products of our own society. ${ }^{170}$ Congress' assertion that it has but to find certain conduct undesirable and then order the expulsion of aliens indulging in such conduct can thus be regarded as the assertion of a broad police power over the alien population. Indeed, both the administration and the consequences of banishment suggest that it is punishment. ${ }^{180}$ It is submitted that no such general police power over aliens exists. ${ }^{181}$

178. Keller v. United States, 213 U.S. 138, 150 (1909) (dissenting opinion).

179. The President's Commission, after setting forth the facts with respect to several examples of expulsion, concluded:

Each of these aliens is the product of our saciety. Their formative years were spent in the United States, which is the only home they have ever known. The countries of their origin which they left-in two cases during infancy, in another, at the age of 5 years-certainly are not responsible for their criminal ways. Their criminal careers are American, not foreign, products. If such a person ofiends against our laws, he should be punished in the same manner as other citizens and residents of the United States and should not be subject to banishment from this country. We cannot expect other countries to take, and continue to take, undesirable people who have no real tie with them.

President's CoMrar's ReP. 202.

The fact that infant immigrants who later become undesirable are the product of our society was eloquently recognized by Judge Learned Hand in Di Pasquale v. Karnuth, 158 F.2d 878, 879 (2d Cir. 1947); United States ex rel. Klonis v. Davis, 13 F.2d 630, 631 (2d Cir. 1926).

180. For recognition of the consequences of deportation, see Trop v. Dulles, 356 U.S. 86, 98 (1958) (dictum); United States v. Spector, 343 U.S. 169, 178 (1952) (dissenting opinion of Jackson, J.) ; Fong Haw Tan v. Phelan, 333 U.S. 6, 10 (1948). The prospeet of possible banishment has been held sufficient to prevent an appeal from a criminal conviction being dismissed as moot. Fiswick v. United States, 329 U.S. 211 (1946).

As to the administration of the program, see Committee on Immigration and Naturalization, Political Deportations in the United States, 14 LAw. Gund REv. 93,112 (1954):

The deportation laws seem often to have been administered with a view to imposing 
For after a long-term residence, the only difference between the alien and his citizen neighbors lies in the alleged foreign allegiance of the alien. Arguably, this difference is significant. Indeed, the more or less articulate premise of the currently accepted view of congressional power over aliens seems to be that to impose limits on the power to expel would be to cripple this country internationally, by depriving the Government of a necessary power of defense and reprisal. ${ }^{182}$ But a critical look at the basic theory underlying this argument will show that it is fallacious.

The concept of continuing foreign ties seems to be the consequence of an uncritical extension of the rule that in time of war enemy aliens are subject to special treatment on the basis of presumed loyalty to the country of nativity, which in turn is based on the theory that the resident alien owes only temporary allegiance to this country, ${ }^{183}$ and in time of war is duty bound to act in the interests of the enemy country from which he originally emigrated, even though he came here as an infant. ${ }^{184}$ But even conceding that in times of war Congress may be said to have no obligation to determine which enemy aliens are in fact loyal and which disloyal does not justify extending the presumption to times of peace. Perhaps there may have been some merit to the theory of temporary allegiance at a time when many immigrants came here intending only to work for a number of years and then to return with their savings to their homes and families abroad and when the sheer volume of immigration was so great that to require inquiry into such matters in deportation proceedings would have seriously obstructed legitimate expulsions. But the quantity of immigration has now been greatly restricted, and, since 1924, the question of intent to become a permanent resident must be determined

on deportees various penalties other than deportation, such as incarccration, the financial expense of lengthy litigation, continuous personal insecurity, loss of cmployment. This hypothesis is supported by a study of three ... factors in the cases: the countries of origin of the deportees; their detention without bail and the amount of bail required pending conciusion of their cases; the length of the proceedings.

See also H.R. REp. No. 1192, 81st Cong., 1st Sess. 7 (1949), admitting that deportation orders could be expected to be nonenforceable in the vast majority of cases owing to the inability of the immigration service to procure travel documents. It would seem that if expulsion were the object of deportation proceedings, the availability of travel documents could be determined before the proceedings were put into motion. Cf. United States $v$. Witkovich, 353 U.S. 194 (1957).

181. See Hines v. Davidowitz, 312 U.S. 52, 76 (1941) (dissenting opinion of Stonc, J.) ; cf. Keller v. United States, 213 U.S. 138 (1909).

182. See Harisiades v. Shaughnessy, 342 U.S. 580, 591 (1952).

183. See, e.g., Radich v. Hutchins, 95 U.S. 210, 211 (1877) ; Carlisle v. United States, 83 U.S. (16 Wall.) 147, 154 (1872).

184. The alien enemy is bound by an allegiance which commits him to lose no opportunity to forward the cause of our enemy; hence the United States, assuming him to be faithful to his allegiance, regards him as part of the enemy resources. It therefore takes measures to disable him from commission of hostile acts imputed as his intention because they are a duty to his sovereign.

Johnson v. Eisentrager, 339 U.S. 763, 772-73 (1950). 
prior to entry. ${ }^{185}$ To presume, therefore, that the majority of the present alien population is here on a temporary basis is not only unrealistic, but is inconsistent with the terms of our immigration laws. In addition, if an alien is a permanent resident, to presume a continuing loyalty to another nation is irrational in view of the human roots that are put down during lengthy residence and the alien's loss of any international-law basis for the protection of his rights by his native country. And, if such presumptions are irrational, then the deprivation of American residence on the basis of such presumptions is unconstitutional. ${ }^{186}$

At worst, the political loyalty of long-term resident aliens might be considered ambiguous, as was suggested by Mr. Justice Jackson in Harisiades. This could, for example, possibly justify Congress' barring them from sensitive jobs for which proof of undivided loyalty is considered a valid requirement. But short of war or a clear retention of ties with the country of nativity, such an argument has no relevance to the question of whether long-term resident aliens are subject to expulsion. For, being long-term residents, their present political beliefs and activities are the product of this rather than some other society. This does not mean that they are immune from criminal sanctions for any unlawful activities, any more than citizens are immune. Nor does it mean that if a particular alien in fact engaged in sabotage or acted as an agent for the country of his nativity he might not be expelled, for then his retention of foreign ties would be clear. But such facts should be established in an appropriate judicial proceeding, relating to the specified individual and his acts, and not by legislative fiat.

Moreover, it should be remembered that the majority of expulsions do not involve considerations of political loyalty, ${ }^{187}$ or involve them only to the ex-

185. See notes 23-31 supra and accompanying text.

186. A conclusive presumption must rest on a rational connection between the ultimate fact presumed and the facts that are proven. Tot v. United States, 319 U.S. 463, 467-68 (1943) ; MccFarland v. American Sugar Ref. Co., 241 U.S. 79, 86 (1916) ; Luria v. United States, 231. U.S. 9, 25 (1913) ; Mobile, J. \& K.C.R.R. v. Turnipseed, 219 U.S. 35, 43 (1910). "[W] here the fate of a buman being is at stake the presence of the evil purpose may not be left to conjecture" Bridges v. Wixon, 326 U.S. 135, 149 (1945).

This argument is also clearly applicable to a conclusive presumption of initial excludability derived from postentry conduct. Unless the legislature may attach the same consequences to the facts giving rise to the presumption as to the facts presumed, the presumption is an unconstitutional infringement of the judicial function. See Heiner v. Donnan, 285 U.S. 312, 329 (1932); Schlesinger v. Wisconsin, 270 U.S. 230, 239-40 (1926); Commissioner v. Clark, 202 F.2d 94, 99-100 (7th Cir. 1953). Thus, if postentry conduct of aliens is subject to congressional regulation only as an incident of the power to cxclude, then prescribing postentry conduct totally divorced from the immigrant's character at the time of entry as a grounds of expulsion is invalid.

187. There are no figures available concerning expulsion from the United States by cause prior to 1908. The totals for the years 1908-1948 are as follows: criminals, 33,550; narcotic offenders, 2,179; immoral classes, 14,814; mental or physical defectives, 26,254; persons previously expelled or excluded, 25,023; overstay of term of authorized residence, 29,055 ; improper or fraudulent entry, 141,161; abandonment of status of admission, 1,483; 
tent that it may be said that this country need not harbor another nation's undesirable human products. But prostitutes and gangsters who have spent most of their lives in this country are not another nation's human products, regardless of where their national loyalty may nominally lie. In short, the presumption of foreign allegiance is irrational in many instances and irrelevant in most. In the few cases in which the presumption is relevant and can be rationally made, or when it can be shown that the alien in fact has foreign ties, the war and foreign relations powers give Congress an adequate means of dealing with him. ${ }^{188}$ Thus the assumption of an unlimited power over all aliens-stemming from "sovereignty"-is both unjustified and unnecessary.

Acceptance of the idea that the power to expel is ordinarily limited to ejection based on proved or reasonably presumed preentry characteristics would have the merit of enabling courts to escape the paradoxical position of eloquently recognizing that banishment is in fact punishment, ${ }^{180}$ while insisting that it is in theory merely a regulatory measure. ${ }^{100}$ Obviously, if expulsion is the "revocation of a privilege voluntarily granted," 101 it must be regarded as a mere civil sanction. ${ }^{192}$ But to characterize banishment as the "revocation of a privilege" merely assumes the existence of a continuing power to expel alien residents. For if the power to expel is constitutionally limited, then at the point in time after which a presumption of his preentry excludability can no longer be rationally made, the alien can be said to have

contract laborers, 2,591; public charges, 22,086; illiterates, 16,754; anarchists, etc., 1,255; Chinese laborers, 2,962; and miscellaneous, 9,051. S. RkP. No. 1515, 81st Cong., 2d Sess. 873-74 (table 5) (1950).

188. But to concede a power to banish under the war power is not to concede unlimited "national emergency" powers. After Harisiades, at least one court still felt that substantive due process standards derived from the first and fifth amendments limited congressional power over aliens. Latva v. Nicolls, 106 F. Supp. 658 (D. Mass. 1952). Yet by drawing a distinction between speech and association, the court was able to hold that the deportation of an alien who had entered in 1916 at the age of 13, maintained an inactive membership in the Communist party in 1934 and 1935, and had apparently remained completely loyal to the United States ever since, was within the power of Congress. Id. at 659-62. It is submitted that if the Government had been forced to justify its action in terms of peacetime power instead of a vague general police or national emergency power over aliens, such a decision would not have been so easily reached. Compare Hesse, The Pre-1917 Cases 1585 n.57.

189. See, e.g., Galvan v. Press, 347 U.S. 522,531 (1954) ; Lehmann v. United States, 353 U.S. 685, 691 (1.957) (dissenting opinion) ; Bridges v. Wixon, 326 U.S. 135, 164 (1945) (concurring opinion); DiPasquale v. Karnuth, 158 F.2d 878, 879 (2d Cir. 1947); United States ex rel. Klonis v. Davis, 13 F.2d 630, 631 (2d Cir. 1926).

190. See, e.g., Galvan v. Press, supra note 189, at 531; Harisiades v. Shaughnessy, 342 U.S. 580,595 (1952).

191. The quotation is from Helvering v. Mitchell, 303 U.S. 391, 399 (1938).

192. See id. at $399 \mathrm{n} .2$. In this footnote, Mr. Justice Brandeis classed disbarment proceedings in the same category with expulsion proceedings. In this connection, comparc Galvan v. Press, 347 U.S. 522 (1954) (expulsion), with Konigsberg v. State Bar, 353 U.S. 252, 266-73 (1957), and Schware v. Board of Bar Examiners, 353 U.S. 232 (1957) (evidence of former communist connections does not justify exclusion from bar). 
acquired the right to remain..$^{193}$ And the deprivation of lawfully acquired rights may correctly be regarded as punishment and the power to impose this punishment limited by the Constitution. ${ }^{104}$ This theory is not only more in accord with the human realities involved in banishment than is the presently accepted view, but it harmonizes completely with the cases on which the present theory is based, since those cases involved illegal or erroneously admitted entrants. ${ }^{195}$

Finally, the recognition that the power to expel is inherently limited and that banishment is punishment would make clear the applicability of the various external limits proposed and rejected in the prior cases. This would give the alien the rights which the Constitution accords to "persons," ending the anomalous practice of protecting his property ${ }^{100}$ while allowing the residence on which his life and liberty may truly be said to depend to be taken away at the Government's will.

\section{Conclusion}

There are occasions when it is for America to make precedents, and not to obey them. We should, if possible, prove a teacher to posterity, instead of being the pupil of bygone generations. More shall come after us than have gone before; the world is not yet middleaged.

Herman Nelville ${ }^{107}$

The acceptance of the preceding constitutional theory would achieve results similar to those urged elsewhere on sociological ${ }^{108}$ and policy grounds. ${ }^{100}$ Obviously, the acceptance of inherent constitutional limits to the power to expel would result in the recognition of an intermediate class of nonexpellable

193. Cf. Bonetti v. Rogers, 356 U.S. 691, 697 (1958) (referring to alien's "right oi lawful presence") ; Keller v. United States, 213 U.S. 138, 150 (1909) ("right to remain") (dissenting opinion).

194. It will be recalled that the basis of Mr. Chief Justice Fuller's dissent in Fong Yue Ting v. United States, 149 U.S. 698, 761 (1893), was his belief that the aliens before the court were in fact lawfully admitted. See Hesse, The Pre-1917 Coses 1593. Accordingly, he argued that "limitations exist or are imposed on the deprivation of that which has been lawfully acquired." 149 U.S. at 762.

195. See note 161 supra.

196. Cf. Russian Volunteer Fleet v. United States, 282 U.S. 481 (1931) (property of alien corporation).

197. MeLvirIe, WHite JACket 150 (Evergreen ed. 1956) (dealing with flogging in the United States Navy).

198. See Committee on Immigration and Naturalization, Political Deporlations in the United. States, 14 LAw. GuILD REv. 93, 99-100 (1954).

199. "The Commission recommends ... that no alien should be subject to deportation who entered the United States for permanent residence before reaching the age of 16 years, or who was lawfully admitted for permanent residence and has resided in the United States for 20 years." President's Conrar'n Rer. 205.

Of 219 political expulsions between the years 1944-1952 studied, $96 \%$ of those for whom facts were available would not be subject to expulsion under the recommendation of the Commission. Committee on Immigration and Naturalization, supra note 198, at 101. 
noncitizens. But such an idea is not unusual. The English common law recognized denizens, whose status, intermediate between citizens and aliens, was obtained by executive grace. ${ }^{200}$ Only recently the Supreme Court has recog. nized the power to create a class of denationalized native born. ${ }^{201}$ More to the point, as a practical matter nonexpellable aliens exist under present immigration laws. ${ }^{202}$ American law has, moreover, recognized examples of nonexpellable noncitizens such as American-born Indians, ${ }^{203}$ and noncitizen nationals. ${ }^{204}$ Neither history nor logic stand in the way, therefore, of constitutional recognition of the human consequences of lengthy American residence.

The acceptance of a class of nonexpellable noncitizens would, on the contrary, merely avoid the precise cases in which the courts have heretofore searched their souls, as well as the statutes, for a means to circumvent congressional intent. In tenaciously retaining the inhumanity of banishment as a part of our constitutional system we can only injure our standing as an ad. vanced, humane society. In this connection, it is noteworthy that both Fong Yue Ting $v$. United States ${ }^{205}$ and Plessy $v$. Ferguson, ${ }^{200}$ decided three years

200. See note 118 supra.

However, the term denizen was apparently used in two senses: a natural born subject, and an alien who has been made a denizen by letters patent of the Crown. See Levy v. McCartee, 31 U.S. (6 Pet.) 102, 117 (1832).

That one enjoying the status of a denizen would have the right to remain here was apparently assumed in Fong Yue Ting v. United States, 149 U.S. 698, 723 (1893). But sec Case of Fries, 9 Fed. Cas. 826, 835 (No. 5126) (C.C.D. Pa. 1799).

The Enemy Alien Act, ch. 66, 1 Stat. 577 (1798), codified in REv. Sxגт. $\$ \$ 4067-70$ (1875), as amended, 50 U.S.C. $\$ \S 21-24$ (1952), recognizes denizens, providing that "all natives, citizens, denizens, or subjects of the hostile nation or government" shall be subject to its provisions. This pruvision has precipitated some judicial consideration of the meaning of the term. See United States ex rel. Zdunic v. Uhl, 46 F. Supp. 689, 691 (S.D.N.Y. 1942), giving various dictionary definitions of "denizen," and holding that one who had resided and worked in Austria from 1922 to 1938 was a denizen of that country, and since, after Austria became a German state, he remained for a short period, he was also a denizen of Germany within the meaning of the Enemy Alien Act. See also United States ex rel. Zdunic v. Uhl, 137 F.2d 858, 861 (2d Cir. 1943).

201. Perez v. Brownell, 356 U.S. 44 (1958).

202. See note 120 supra.

203. Citizenship was not conferred on native-born Indians until 1924. Act of Junc 2, 1924, ch. 233, 43 Stat. 253. See also Act of Jan. 25, 1929, ch. 101, 45 Stat. 1094. But Congress, in excluding them from the definition of "alien" as used in both the 1917 and 1924 acts, was careful not to attempt to expel them. Ch. 29, §1, 39 Stat. 874; ch. 190, § 28(b), 43 Stat. 168.

There is the further possible example of free Negroes prior to the ratification of the fourteenth amendment. Cf. Dred Scott v. Sandford, 60 U.S. (19 How.) 393 (1857).

204. The definitions of "alien," cited note 203 supra, had also excluded from their scope the noncitizen national, who had been held not subject to exclusion. Gonzales v. Williams, 192 U.S. 1 (1904). But this fact did not prevent Filipinos from having the status of an alien thrust upon them even though they had acted upon their American nationality and had come to this country. See Rabang v. Boyd, 353 U.S. 427 (1957).

205. 149 U.S. 698 (1893).

206. 163 U.S. 537 (1896). 
later, were constitutional products of the nineteenth century. Yet only one week before Galvan v. Press, ${ }^{207}$ which refused to reconsider the constitutional issues supposedly settled by Fong Yue Ting despite the recognized merits of a different view, the Court in Brown v. Board of Edusc. ${ }^{208}$ refused to follow Plessy. ${ }^{209}$ It seems safe to suggest, moreover, that while the international consequences of rejecting the power to banish would be as favorable to our interests and standing as those flowing from Brown, ${ }^{210}$ the domestic consequences, in contrast, would be negligible.

It is time that we fully recognize that our nation was built to a great extent by the labor of aliens, ${ }^{211}$ and that we owe it to the nations who have given us their youth, to the native-born children and spouses of aliens, and to the alien population itself, to accept the responsibility for our own human products, good or bad. American history does not support banishment-"universally decried by civilized people."212 But even if it did, the rule supporting such inhuman power should be rejected "as a relic from a different era."13 This does not mean that Congress should be denied full power to reject immigrants, but merely that the power to expel which is, after all, implied from the implied power to exclude, should be recognized as one of those classes of cases calling for "limitation to the least possible power adequate to the end proposed."214

207. 347 U.S. 522 (1954).

208. 347 U.S. 483 (1954).

209. It should be noted, moreover, that Plessy was decided by a 7-1 majority, while Fong Yue Ting enjoyed the support of only 5 justices. See Hesse, The Pre-1917 Cases 1592 n.97.

210. We cannot develop an effective foreign policy if our immigration laws negate our role of world leadership. We cannot defend civil rights in principle, and deny them in our immigration laws and practice. We cannot boast of our magnificent system of law, and enact immigration legislation which violates decent principles of legal protection.

Prestoent's Consrin' Rep. $x v$.

211. See Henderson v. Mayor of New York, 92 U.S. 259, 270 (1876); Preswent's COMIMYN REP. xiv.

212. Trop v. Dulles, 356 U.S. 86, 102 (1958) (opinion of Warren, C.J.). See also United States ex rel. Klonis v. Davis, 13 F.2d 630, 631 (2d Cir. 1926) (L. Hand, J.).

213. The quotation is from Reid v. Covert, 354 U.S. 1, 12 (1957) (Black, J.).

214. United States ex rel. Toth v. Quarles, 350 U.S. 11, 23 (1955) ; Anderson v. Dunn, 19 U.S. (6 Wheat) 204, 230-31 (1821). See also Keller v. United States, 213 U.S. 138 (1909). 


\section{THE YALE LAW JOURNAL}

\section{Alan Appelbaum \\ Editor-in-Chief}

\author{
JAMES M. EdWARdS \\ STEPHEN MANN \\ Donatd G. Marshall \\ ROBERT L. WEINBERG \\ Note \& Comment \\ Editors
}

JAMES MCC. JOHNSTONE

Gildert PaUl Vekdit Article \& Book Review Editors

Eugene I. LaMaerT Managing \& Case Editor
Matrhew T. Adams

David Albenda

Hurd Baruch

Arthur J. Berk

JaN G. Deutsch

EtIezer EretI

David R. Evans

Stuart B. Golduan

LAWRENCE G. GOODMAN
Richard S. Harrison Benjanin T. Hopkins, II Robert E. Hudec ZaNe KIEIN

N. Herschel Koblenz Bruce Montgonery Samuet Myers Michael J. Nassau
J. Alexander ONderdonk Alan D. Pekelnen Herbert Scureiner Richard Lauder Sutton Herbert S. Wander DONALD P. WEFER Patricia W. Weinuerg SidNey M. Wolinsky JERE A. YOUNC:

Marie McMahon

Business Secretary

\section{CONTRIBUTORS TO THIS ISSUE}

Peter F. Coogan. LL.B. 1939, Western Reserve University; LL.M. 1942, Harvard University. Lecturer, Harvard Law School; Visiting Lecturer, Yale Law School. Member of the Massachusetts and Federal Bars. Member of the firm of Ropes, Gray, Best, Coolidge \& Rugg, Boston.

JoH N Bok. A.B. 1952, LL.B. 1955, Harvard University. Member of the Massachusetts and Federal Bars. 'Associated with the firm of Ropes, Gray, Best, Coolidge \& Rugg, Boston.

Siegrried Hesse. A.B. 1946, University of Southern California ; LL.B. 1950, University of California (Berkeley). Member of the Washington Bar. Managing Legal Editor, California Continuing Education of the Bar. 